Fiscal POLICY AND MACROECONOMIC STA BILISATION IN THE EURO AREA: POSSIBLE Reforms of the Sta BILITY AND GROWTH PACT AND NATIONAL DECISION-MAKING PROCESSES

The recent economic-policy debate in the $\mathrm{EU}$ has largely focused on fiscal policy and the Stability and Growth Pact. The reason is the current budgetary problems of some member states. Portugal breached the three-percent-of-GDP deficit ceiling in 2001 and 2002. G ermany breached it in 2002, and may also do so in 2003. France and Italy have abandoned their commitments to earlier agreed budget objectives and there is a clear threat that they may violate the deficit ceiling, too. These events have contributed to a revival of the debate on the fiscal policy framework in the EU. The European Commission has recently proposed a number of changes in the Stability and Growth Pact (E uropean Commission, 2002b). There have also been calls for more fundamental revisions of the EU fiscal policy framework including proposals to scrap the Stability and Growth Pact altogether (see, for example, Financial Times, 2002a,b,c; Economist, 2002; de Grauwe, 2002; or Walton, 2002).

A key issue is the need to combine long-run sustainability of fiscal policy with short-run flexibility as a tool for macroeconomic stabilisation. The current EU fiscal rules mainly reflect a desire to enhance long-run fiscal discipline. This is explained by the earlier rapid accumulation of government debt, but also by the view that discretionary fiscal policy is unsuitable as an instrument of countercyclical stabilisation. A t the same time, the risk of asymmetric cyclical developments in individual euro countries creates a potential need for using national fiscal policy as a stabilisation tool. This has led to a criticism that the EU fiscal rules are too rigid and hamper the use of fiscal policy for stabilisation purposes in an inappropriate way. The rules have also been criticised for being arbitrary. A the same time, the current discussion illustrates very clearly that it may be very difficult to apply the rules in a sufficiently disciplining way when they are put to a real test.

One aim of this chapter is to analyse what role fiscal policy should play as a stabilisation tool in the euro area. In line with other recent contributions, we argue that this role should be larger than according to the conventional wisdom that has prevailed in recent years. We also argue that this requires changes in the fiscal policy framework at the EU level. Recent proposals of the European Commission seek to make the EU fiscal rules more flexible through changes in the interpretation of the Stability and Growth Pact and a greater reliance on discretionary judgements. We argue that this approach is potentially harmful and that more fundamental reforms, implying changes in the $M$ aastricht Treaty, are required. There is a case for letting the deficit ceiling in the Treaty depend on the debt level in a transparent way. Countries with low debt should be allowed to run larger budget deficits than three percent of GDP. This would serve both to give low-debt countries greater scope for stabilisation policy and to enhance the incentives for fiscal discipline. A nother recommendation is that the decisions on sanctions against EMU member states that violate the deficit ceiling should be moved from the political level of the Ecofin Council ${ }^{1}$ to the judicial level of the E uropean Court of Justice. This would make the enforcement of the fiscal rules more credible.

Changes in the EU fiscal rules involve difficult trade-offs. On the one hand, if the rules are perceived as too rigid and arbitrary by the public, their legitimacy will gradually evaporate and they will become unsustainable. $\mathrm{O} n$ the other hand, the credibility of the fiscal policy framework must not be undermined by an impression that the rules are changed in a discretionary way as soon as they begin to bite, especially for the large EU countries. There is a continued need for fiscal rules at the EU level to enhance the incentives for fiscal discipline. The future burdens of ageing populations make large reductions of government debt highly desirable. Therefore, the medium-term budget objective of "close to balance or in surplus" should be maintained, although it should be made explicit that it is set in cyclically adjusted terms.

\footnotetext{
1 The Council of M inisters of the E uropean U nion is termed the E cofin Council when it is made up of the economics and finance ministers of the member states.
} 
Current events have, however, illustrated that there are limits to how much fiscal rules at the $\mathrm{EU}$ level can achieve on their own. Governments are likely always to shun away from political conflicts about each others' fiscal policies. This is an argument for relying to a much larger extent than hitherto on national institutions that are conducive to both long-run fiscal discipline and effective shortrun stabilisation policy. This can be seen as an application of the general principle of subsidiarity (see Chapter 3). One step in this direction would be to require the member states to adopt laws on fiscal policy that set well-defined long-run sustainability goals which are consistent with the common EU objectives, but also outline clear principles for the use of fiscal policy as a stabilisation tool.

A lthough it is clearly not on the political agenda now, one should also explore the future possibilities of reforming the national decision processes for fiscal policy along the lines of monetary policy, as has recently been suggested in a number of contributions. N otwithstanding that the idea may seem unfamiliar to many, there is a case for trying to separate fiscal policy decisions with the aim of stabilising the economy from other types of fiscal policy decisions. One possibility might be delegation to an independent national fiscal policy authority. Such delegation would be in line with developments in other areas such as competition policy as well as financial regulation and supervision, where in many countries the operational conduct of policy has been delegated to various bodies, and politicians have focused more on setting the overall objectives. D elegation of national fiscal policy decisions could also be seen as an alternative to the larger role in fiscal policy surveillance desired by the European Commission (European Commission, 2002b).

The underlying motive for delegation at the national level is a desire to mitigate the problems hampering the use of fiscal policy as a stabilisation instrument: long decision lags, irreversibility of decisions, risks of contributing to a deficit bias, "confounding" of various objectives and so on. However, it remains an open question whether one could find forms of fiscal policy delegation that would be accepted by the general public. The most realistic possibility in the near future might be to require the government to consult with an independent fiscal policy committee before making its budget decisions and to base these on the committee's estimates of the cyclical situation and its forecasts of government revenues and expenditures.

The chapter is structured as follows. Section 1 reviews the role of fiscal policy as a tool of stabilisation policy both in general and in the specific E M U context. Section 2 analyses the case for modifications of the current fiscal policy framework in the $E U$. Section 3 discusses the possibilities to strengthen the fiscal policy framework at the national level and the case for letting an independent fiscal authority play a larger role.

\section{Fiscal policy as a stabilisation tool}

The perception of the role of fiscal policy has changed radically over recent decades. D iscretionary fiscal policy to stabilise the economy has come to be regarded with great scepticism. Instead, the conventional wisdom today is that monetary policy should be the main stabilisation tool.

O ne explanation of this development is, of course, the large accumulation of government debt in most OECD countries in the 1980s and early 1990s, which is unprecedented in peacetime (see Figure 2.1). A s a consequence, fiscal sustainability has become the main fiscal policy issue, and major reforms of the fiscal policy framework have been undertaken in nearly all OECD countries. These reforms include both various fiscal policy rules, like the ones in the Maastricht Treaty and the
Figure 2.1

Gross GovernMENT DEBT/GDP, 1970 - 2003

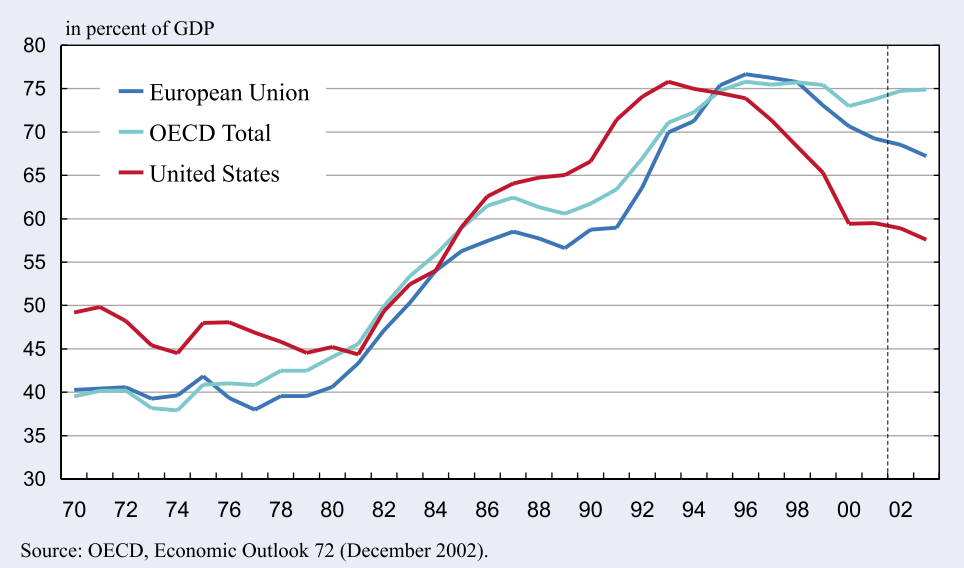


Stabilisation and Growth Pact, and procedural changes in the national budget processes in various countries (see, for example, Kopits and Symansky, 1997; and von Hagen et al., 2002). In terms of academic research, the problems with accumulating government debt have stimulated a large body of literature explaining why unconstrained fiscal policy may involve a permanent deficit bias (see A lesina and Perotti, 1995, for a survey).

Two major types of theoretical objections have been raised against using fiscal policy for stabilisation purposes. The first one questions the technical effectiveness of such policies. The second objection questions the ability of policy makers to use fiscal stabilisation policy in an effective way.

The discussion of the technical effectiveness of fiscal policy takes its starting point in the notion of so-called Ricardian equivalence (see Elmendorf and M ankiw, 1999, for a survey). The argument is that tax reductions or transfer increases that raise the disposable incomes of households will fail to increase private consumption if they involve larger budget deficits: households will realise that their life-cycle incomes have not increased, as they will have to pay for the deficits through higher taxes or lower transfers in the future. A nother argument holds that tax reductions or government expenditure increases could even give rise to perverse negative demand effects if they are associated with credibility problems that lead to increased interest rates or to expectations of future "crisis adjustments" that will lower life-cycle incomes (see, for example, G iavazzi and Pagano, 1996; and G iavazzi et al., 2000).

There are a number of arguments why discretionary fiscal policy may be used in a less effective way as a stabilisation tool than monetary policy.

- D ecision lags are longer, as tax and expenditure changes have to go through a lengthy parliamentary decision-making process, which is usually annual in contrast to the almost continuous decision-making process for monetary policy.

- The political character of fiscal policy decisions makes it much harder to reverse decisions when circumstances change than is the case for monetary policy (Taylor, 2000).

- Fiscal policy has other central goals than stabilisation, viz. income distribution and resource allocation. In addition, fiscal policy measures are often influenced by attempts of incumbent governments to enhance their reelection chances. $\mathrm{H}$ ence there is the serious risk that the stabilisation aspects will carry a low weight.

- The risk of an expansionary bias is much larger for fiscal policy than for monetary policy, as the former is run by policy-makers engaged in dayto-day politics, whereas the latter has been delegated to independent central banks, which can take a more long-run view.

The conclusion has been that fiscal stabilisation policy is likely to be badly timed and procyclical, especially in booms because it is politically much more difficult then to pursue restrictive policies than it is to pursue expansionary policies in recessions. ${ }^{2}$

The current conventional wisdom is that fiscal policy should mainly be confined to letting the automatic stabilisers work, that is to let the automatic variations in the budget balance that follow from the cyclical variations in tax receipts and some government expenditures, such as unemployment benefits and costs for labour market programmes, dampen the business cycle (see, for example, Taylor, 2000; Buti and Martinot, 2000; Buti and Giudice, 2002; or European Commission, 2002a). B ecause of their "automatic" character, such policies do not raise the same problems of decision lags, deficit bias and problems of reversing policies in new situations as have traditionally been associated with discretionary fiscal policy. The size of the automatic stabilisers are positively related to the share of government expenditure in GDP, the degree of tax progressivity and the generosity of unemployment compensation. R ecent empirical research does indeed confirm that large government sectors, and thus large automatic stabilisers, reduce output volatility to a significant degree (G ali, 1994; Fatàs and M ihov, 2001, 2002). ${ }^{3}$

\subsection{The case for discretionary fiscal policy}

Adopting a more long-term perspective, it has been noted that there have been large swings over time in the relative emphasis given to fiscal and

2 This seems indeed to be vindicated by past experiences according to, for example, Leibfritz et al. (1994), Buti et al. (1997), and European Commission (2001). But these empirical conclusions have to some extent been challenged by M élitz (2002) and Wyplosz (2002).

${ }^{3} \mathrm{~A}$ ccording to Fatàs and M ihov (2002), an increase in the ratio of government expenditure from 40 to 50 per cent of GDP reduces the standard deviation of real GDP growth among the OECD countries by around 0.5 . 
monetary policy as stabilisation tools (Wyplosz, 2002a). This raises the possibility that the present downplaying of fiscal policy as a stabilisation instrument may have gone too far. Indeed, this has recently been suggested in a number of contributions, such as B all (1997), W ren-L ewis (2000, 2002), von Hagen (2001), Seidmann (2001), Blanchard and Perotti (2002), Fàtas and Mihov (2002), and Wyplosz (2002a), who all have argued for a revival of the role of fiscal policy.

There are several reasons why relying on discretionary monetary policy may not be enough in many situations.

A well-known argument is that monetary policy may be impotent in a depression when it can be caught in a liquidity trap, because it is impossible to achieve negative real interest rates in situations with falling prices. Japan is an obvious case in point (see the B ox on Japan in Chapter 1 in this report). But also in more normal situations, there may be limitations to monetary policy because central banks are reluctant to change interest rates by much in the short run, as this would imply large variations in the prices of outstanding debt (interest rate smoothing).

It has also been claimed that fiscal policy can more easily be targeted in a desirable way than monetary policy. Ball (1997) and W ren-Lewis (2000, 2002) argue that fiscal policy can be designed so as to have more even effects across the economy than monetary policy, which will have a greater impact on construction and investment goods sectors than on service sectors. These more even effects may be desirable in some situations. In other situations, one may want to target measures more specifically, for example to counteract a real property price boom, which may be easier through targeted fiscal policy (such as reductions of tax relief for mortgage interest rates) than through monetary policy.

The strongest argument in favour of fiscal policy in the euro area is the risk of asymmetric cyclical developments in individual countries. In the event of such macroeconomic disturbances, national fiscal policy is the only remaining stabilisation policy tool. There is an obvious case for such stabilisation policy in recessions, as money wages, and thus also prices, tend to be rigid downwards (Calmfors, 1998; Calmfors et al., 2001). The case for stabilisation policy in booms is somewhat more complex. $\mathrm{A}$ relative price increase vis-à-vis other countries ( $a$ real exchange rate appreciation) may be a proper adjustment to macroeconomic shocks that raise output growth. Whether or not this is the case depends, as was discussed in last year's E EA G report (EEA G , 2002), on the character of the shocks. In the case of permanent structural changes, such as a permanent increase in the relative demand for a country's output or a permanent increase in the relative productivity of a country, prices could just be left "to do their job". But this is not an appropriate response in the case of a temporary asymmetric demand increase. The main reason is again downward money wage rigidity: inflation in a temporary boom tends to cause "permanent" wage increases that are hard to reverse and therefore "lock in" real exchange rate appreciations. This makes it more difficult to stabilise the economy in the next recession, as the real exchange rate appreciation requires a more expansionary fiscal policy with larger budget deficits than would otherwise be the case (Swedish Government Commission on Stabilisation Policy in the EMU, 2002). The main rationale for fiscal stabilisation policy in a boom is thus intertemporal considerations relating to future stabilisation possibilities. ${ }^{4}$

A related intertemporal argument for fiscal stabilisation policy in booms in the E M U countries is the risk of strong asset price reversals, that is boombust cycles in asset prices where first large asset price rises reinforce the upswing and then large asset price falls exacerbate the downswing. A gain the most obvious recent example is Japan. The macroeconomic consequences of such excessive asset price volatility has recently been studied by Bordo and Jeanne (2002), who find boom-bust cycles to be much more common in real property prices than in stock prices and to be associated with large cyclical swings in output. This finding is highly relevant for stabilisation policy in the EM U countries, because cycles are much more likely to be country-specific in real property prices than in stock prices. Interestingly, Bordo and Jeanne (2002) also find boom-bust cycles in real property prices to be more common in small than in large countries, which they explain by the larger relative importance of local markets in small countries (the

\footnotetext{
${ }^{4}$ Some of the discussion on to what extent "prices should be left to do their job" has focused on whether demand shocks are internal or external. It has been argued that price adjustments are appropriate only in the latter case (Blanchard, 2001; E uropean Commission, 2002a). In our view, these are not the relevant considerations, because a temporary increase in external demand is as problematic as a temporary increase in internal demand if it leads to a real exchange rate appreciation that is hard to reverse.
} 
relative size of the Stockholm area in Sweden is larger than that of the B erlin area in G ermany).

Why are automatic stabilisers not likely to be a sufficient fiscal policy tool in the case of large cyclical asymmetries in the euro area? There are a number of reasons.

- By their very nature automatic stabilisers can only cushion macroeconomic shocks, but not fully offset them. A ccording to most estimates, automatic stabilisers reduce output fluctuations by around a third in the EU countries (see, for example, van den Noord, 2000; and European Commission, 2002a).

- A s discussed above, the size of the automatic stabilisers is positively related to the share of government expenditure in GDP, the degree of tax progressivity and the generosity of unemployment compensation. But the decisions on such structural parameters have not been influenced much by stabilisation concerns: instead the size of automatic stabilisers is a by-product of other considerations, such as preferences over private versus public consumption or over income distribution versus allocative efficiency. There is no reason, therefore, to believe that the automatic stabilisers give an optimal degree of stabilisation. Nor should one expect that differences in the size of the automatic stabilisers among countries, for example due to differences in the share of government expenditures in GDP, as shown in Table 2.1 , reflect differences in the preferences for stabilisation. Countries with small automatic stabilisers may therefore want to use discretionary fiscal policy more than others.

- Structural reforms in the European economies with the aim of raising long-run employment and growth has weakened the automatic stabilisers. This is evident from Table 2.1, which shows the reduction in the size of government in recent years (from an unweighted average in the $E U$ of 45.0 percent of GDP in 1994 to 41.7 percent in 2002). In addition, tax progressivity and the generosity of unemployment benefits (mainly in terms of coverage but also to some extent in terms of benefit levels and duration) have - for good reasons - been reduced (see E EA G, 2002; as well as the Box on Germany in Chapter 1 in this report).

- Finally, if there are permanent supply shocks, the automatic stabilisers tend to prolong the adjustment process and cause budget effects
Table 2.1

G overnment spending, excluding interest payments, as a percentage of G DP in the $E U$ countries

\begin{tabular}{|c|c|c|c|c|}
\hline & 1994 & 1998 & 2001 & 2002 \\
\hline A ustria & 49.2 & 47.0 & 47.7 & 48.2 \\
\hline Belgium & 41.5 & 40.7 & 40.3 & 40.4 \\
\hline Germany & 43.1 & 42.7 & 42.7 & 43.0 \\
\hline D enmark & 54.7 & 51.5 & 48.9 & 49.5 \\
\hline Spain & na & 35.2 & 34.6 & 34.8 \\
\hline Finland & 56.4 & 46.4 & 43.6 & 44.2 \\
\hline France & 48.5 & 46.7 & 45.9 & 46.6 \\
\hline Greece & 32.1 & 34.9 & 36.6 & 37.2 \\
\hline I reland & 36.6 & 29.9 & 29.9 & 31.4 \\
\hline Italy & 41.7 & 39.8 & 40.5 & 40.8 \\
\hline L uxembourg & 43.7 & 40.9 & 39.5 & 43.3 \\
\hline Netherlands & 43.2 & 39.2 & 39.3 & 40.3 \\
\hline Portugal & 36.6 & 36.7 & 38.9 & 38.4 \\
\hline Sweden & 62.9 & 52.7 & 50.1 & 50.9 \\
\hline U nited $\mathrm{K}$ ingdom & 40.0 & 34.6 & 36.3 & 37.0 \\
\hline U nweighted average & 45.0 & 41.3 & 41.0 & 41.7 \\
\hline Standard deviation & 8.2 & 6.4 & 5.4 & 5.4 \\
\hline Coefficient of variation & 0.18 & 0.15 & 0.13 & 0.13 \\
\hline \multicolumn{5}{|c|}{$\begin{array}{l}\text { Note: The budget balance can be written } B=t Y-G \text {, where } \\
B \text { is the budget surpuls, } t \text { is the tax rate, } Y \text { is real } G D P \text { and } \\
G \text { is real government expenditure. } D \text { ividing by } Y \text {, we have } \\
b=B / Y=t-G / Y \text {, where } b \text { is the budget balance as a ratio } \\
\text { of } G D P \text {. D ifferentiation with respect to } b \text { and } Y \text { gives } \\
d b=(G / Y) d Y / Y \text {. So, } G / Y \text { is the semi-elasticity of the } \\
\text { budget surplusas percentage of } G D P \text { with respect to real } \\
\text { output, that is it indicates by how many percentage points } \\
\text { of GDP the fiscal balance improves when output rises by } \\
\text { one percent. }\end{array}$} \\
\hline
\end{tabular}

Source: OE CD E conomic O utlook 72 (D ecember 2002).

that must ultimately be eliminated through discretionary action.

$1.2 \mathrm{H}$ ow effective is fiscal policy as a demand management tool?

The discussion on Ricardian equivalence has contributed to the impression that fiscal policies are not very effective (see Elmendorf and Mankiw, 1999). Much of this discussion is, however, rather superficial as it tends to lump together various fiscal policies that should theoretically be expected to have very different effects.

The ineffectiveness postulate of $\mathrm{R}$ icardian equivalence applies only to tax and transfer changes that affect the real disposable income of households. The postulate holds only under very restrictive assumptions: households must have a long enough time horizon for taking into account offsetting future tax and transfer changes and they must not be credit-constrained. O ne would expect the former assumption to be more valid in situations of pressing government debt problems when the public debate focuses on sustainability issues (as in the 1990s) than in more normal times (like now). O ne would always expect those tax and transfer 
changes to be effective that are targeted on lowincome groups, which to a large extent are creditconstrained (W ren-L ewis, 2000, 2002). Such targeting may also be motivated from a welfare point of view, as these groups are more exposed to cyclical income volatility than groups with higher incomes (Storesletten et al., 2001).

M ost empirical evidence seems to support substantial demand effects of tax changes. The evidence that automatic stabilisers, which work mainly on the tax side, reduce the volatility of output and consumption, is not consistent with $\mathrm{R}$ icardian equivalence ( $G$ ali, 1994; F àtas and M ihov, 2001, 2002). B lanchard and Perotti (1998) recently found a multiplier of close to one for discretionary tax changes in the U.S., whereas other studies have found somewhat lower multipliers (W ren-L ewis, 2000, 2002; Wijkander and R oeger, 2002; Swedish G overnment Commission on Stabilisation Policy in the EMU, 2002; E uropean Commission, 2002a).

Temporary changes in government consumption also have an effect on aggregate demand under $\mathrm{R}$ icardian equivalence. This is obvious if an increase in current government consumption is financed through a reduction in future government consumption, as this involves no change in the taxes paid by households and hence no change in private consumption. But a similar conclusion holds also if a temporary increase in government consumption is financed through future taxes. The explanation is that the short-run direct demand effects are larger than the short-run effects on private consumption due to future tax changes: this is so because the changes in private consumption resulting from the changes in life-time incomes will be spread over the whole future, as households want to smooth consumption over time, whereas the entire change in government consumption occurs in the short run. The positive output effects of increases in government consumption have been confirmed in a number of recent empirical studies (for example, R otemberg and Woodford, 1992; Ramey and Shapiro, 1997; E delberg et al., 1998; Fàtas and M ihov, 1999; and B lanchard and Perotti, 1999). In most cases multipliers around one are found. Some of the studies find that increases in government consumption are associated with increases in private consumption - and not decreases as implied by Ricardian equivalence (Blanchard and Perotti, 1999; Fàtas and Mihov, 1999). O ther work has found that the fiscal multipliers for government consumption are larger than for income taxes (W ren-L ewis, 2000, 2002; Wijkander and R oeger, 2001; E uropean Commission, 2002a).

In the economic-policy discussion there is a tendency to associate fiscal policy mainly with measures that affect aggregate demand either via direct expenditure changes or via tax and transfer changes that have an impact on the disposable income of households. But fiscal policy can also work by changing relative prices. $O$ ne such policy, which has been used at times in Sweden, is temporary changes in VAT (see also B linder, 2001; Wijkander and R oeger, 2002; E uropean Commission, 2002a; Swedish G overnment Commission on Stabilisation Policy in the EMU, 2002; and W ren-L ewis, 2002). A temporary change in VAT affects private consumption in a similar way as a change in the real interest rate: by changing the relative price between consumption in different time periods, households are induced to reallocate consumption spending intertemporally. O ne could also conceive of a similar use of investment taxes or subsidies to affect the timing of private investment (Swedish G overnment Commission on Stabilisation Policy in the E MU, 2002; W ren-L ewis, 2002). There is some evidence that the fiscal multipliers are considerably larger for VAT than for income taxes (W renLewis, 2000, 2002; Wijkander and Roeger, 2002; E uropean Commission, 2002a).

Cross-border trade usually limits the possibilities to set VAT rates according to national priorities. $B$ ut this does not apply in the same way to temporary VAT changes as a stabilisation tool in the case of asymmetric cyclical developments. On the contrary, if a temporary rise in national VA T in a boom shifts consumption purchases abroad, this, too, tends to reduce demand domestically. A potential risk of using temporary VAT increases to dampen an asymmetric boom in a euro country is, however, that they could trigger "permanent" wage increases, although the risk is much smaller than in the case of permanent VAT changes.

A nother possibility, which has also been overlooked in much of the international discussion, is to use temporary variations in the payroll taxes levied on employers as a discretionary stabilisation tool. By changing wage costs, such a policy directly affects the real labour cost and the real exchange rate. It thus represents a way of letting prices do their job in the case of asymmetric cyclical developments. However, since real exchange rate changes are known to affect trade volumes with 
substantial lags, such a policy would seem relevant mainly in the case of relatively drawn-out disturbances. It is not only temporary reductions in payroll taxes in downswings that may be of interest. In fact, temporary rises in employers' payroll taxes may be a very appropriate policy if an individual euro country experiences an asymmetric boom. The reason is that higher payroll taxes for employers raise domestic wage costs and output prices, but not domestic wages. On the contrary, wages are likely to fall to the extent that the demand for domestic output falls and the tax is shifted backwards on to employees because the "room for wage increases" is reduced. ${ }^{5}$

The upshot is that a temporary increase in employers' payroll taxes may be a desirable way of dampening a boom, because wage costs are temporarily raised at the same time as the risk is reduced that wages are bid up more permanently. The idea of using cyclical variations in employers' payroll taxes in this way has large similarities with the system of so-called buffer funds that was set up in Finland in connection with the entry into the EMU. A ccording to this system, funds have been built up through a temporary increase in various employer contributions to the social security system with the intention to use the proceeds of these funds to hold down contributions in downswings (Calmfors, 1998; Holm et al., 1999; Swedish Government Commission on Stabilisation Policy in the E M U, 2002). 6

O ur conclusion is that discretionary fiscal stabilisation policy is potentially effective and that occasions are likely to arise in the euro countries when its use would be desirable. We are not thinking about "fine tuning", but about countercyclical stabilisation in the event of major macroeconomic disturbances. This does,

5 This latter tax-shifting effect has been shown to be empirically strong in the Nordic countries (see Calmfors and Nymoen, 1991; Rødseth and Nymoen, 1999; and Calmfors and Uddén Sonnegård, 2001). The effects mentioned in the text could be counteracted, because compensating wage claims are triggered by the CPI rises associated with higher output prices when payroll taxes are increased, but this effect is likely to be small compared to the other effects.

${ }^{6} \mathrm{~A}$ s unemployment benefits were earlier financed on a purely "pay-as-you-go" basis in Finland, variations in employer contribution rates had a procyclical impact on the economy with rates going up in recessions and down in booms.

Table 2.2 however, require a fiscal policy framework that prevents misuse of stabilisation measures that causes excessive debt accumulation. It also requires addressing the problems of long decision lags and irreversibility of fiscal policy measures. The problem of decision lags is perhaps most obvious in the case of temporary VAT changes: it is a serious problem if, for example, a temporary increase in VAT in a boom can be decided only in a lengthy political process, as the anticipation of the measure will lead to effects that are the reverse of those desired in the period before the measure came into force. The problem of irreversibility is most clear-cut for increases in government consumption in a recession. A s we have argued, this is likely to be a more effective stabilisation tool than general cuts in personal income taxes, but there is a serious risk of political "ratchet effects" making it impossible to reduce government consumption again in the next boom (Wijkander and R oeger, 2002). We shall return to these issues in Section 3, after first having discussed the fiscal rules at the $E U$ level and their impact on the possibilities to pursue stabilisation policies.

\section{Possible reforms of $E U$ fiscal rules}

The "raison d'être" for the fiscal rules in the $E U$ is the desire to ensure long-run sustainability of public finances, which came under threat in the 1980s and early 1990s because of the rapid build-up of government debt in most member countries. This is shown in Table 2.2 .

G ross government debt as a percentage of $G D P$ in the $E U$ countries, $1980-2003$

\begin{tabular}{|l|rrrrrrr|}
\hline & 1980 & 1990 & 1995 & 2000 & 2001 & 2002 & 2003 \\
\hline B elgium & 78.6 & 129.2 & 133.9 & 109.2 & 107.6 & 105.6 & 101.7 \\
D enmark & 36.5 & 57.8 & 69.3 & 46.8 & 44.7 & 44.0 & 42.4 \\
G ermany & 31.7 & 43.5 & 57.0 & 60.2 & 59.5 & 60.9 & 61.8 \\
G reece & 25.0 & 79.6 & 108.7 & 106.2 & 107.0 & 105.8 & 102.0 \\
Spain & 16.8 & 43.6 & 63.9 & 60.5 & 57.1 & 55.0 & 53.2 \\
France & 19.8 & 35.1 & 54.6 & 57.3 & 57.3 & 58.6 & 59.3 \\
Ireland & 75.2 & 101.5 & 82.6 & 39.1 & 36.4 & 35.3 & 35.0 \\
Italy & 58.2 & 97.2 & 123.2 & 110.6 & 109.9 & 110.3 & 108.0 \\
L uxembourg & 9.3 & 4.4 & 5.6 & 5.6 & 5.6 & 4.6 & 3.9 \\
N etherlands & 46.0 & 77.0 & 77.2 & 55.8 & 52.8 & 51.0 & 50.1 \\
A ustria & 36.2 & 57.2 & 69.2 & 63.6 & 63.2 & 63.2 & 63.0 \\
Portugal & 32.3 & 58.3 & 64.3 & 53.3 & 55.5 & 57.4 & 58.1 \\
Finland & 11.5 & 14.3 & 57.2 & 44.0 & 43.4 & 42.4 & 41.9 \\
Sweden & 40.3 & 42.3 & 76.2 & 55.3 & 56.6 & 53.8 & 51.7 \\
U nited K ingdom & 53.2 & 34.0 & 51.8 & 42.1 & 39.1 & 38.5 & 38.1 \\
\hline U nweighted average & 38.0 & 58.3 & 73.0 & 60.6 & 59.7 & 59.1 & 58.0 \\
G D P-weighted average & 38.0 & 54.4 & 70.2 & 64.1 & 63.0 & 63.0 & 62.5 \\
Standard deviation & 20.5 & 32.5 & 30.2 & 27.5 & 27.7 & 27.8 & 26.9 \\
Coefficient of variation & 0.5 & 0.6 & 0.4 & 0.5 & 0.5 & 0.5 & 0.5 \\
\hline Note: The 1980 and 1990 figures for G ermany refer to west G ermany. & \\
\hline
\end{tabular}

Source: European Commission (2002c). 
There are two main motives for fiscal rules at the EU level. The first - and in our view the most important - motive is to enhance fiscal discipline in general. The need for this has been emphasised by an extensive political-economy literature, which has pointed out how a large number of factors may cause a deficit bias (see, for example, A lesina and Perotti, 1995; or von $\mathrm{H}$ agen et al., 2002). These factors include: (i) fiscal illusion on part of the general public; (ii) the fact that it is politically more popular to stimulate demand in recessions than to restrain it in booms; (iii) the use of debt by incumbent governments as a strategic variable to favour their own constituencies and constrain the policies of future governments in favour of other constituencies; (iv) distributional conflicts; (v) lobbying by local constituencies for targeted benefits, the costs of which are shared nationally; and (vi) problems of time inconsistency, according to which governments cannot resist ex post the temptation to abandon sound fiscal policy even if it is clear ex ante that this is inappropriate.

The desire to strengthen budgetary discipline in general is not related to EMU per se. Rather, in a situation of general fiscal profligacy, monetary unification offered a unique opportunity to establish constraints on government budget deficits and debt accumulation at the $E U$ level. A s the creation of $E M U$ required the set-up of new institutions anyway, it appeared much easier to establish such rules at the EU level than to initiate national reform processes, which could more easily be blocked by various vested interests. In this perspective, the role of an "external enforcer" of budgetary discipline that the EU has assumed can be seen as an outcome of very specific historic circumstances.

The second motive for fiscal rules at the EU level is the moral-hazard problems that can arise in a monetary union because fiscal policies in one member state have spillover effects on the other states. A number of such spillover effects have been identified (see, for example, Buiter et al., 1993; or B eetsma, 2001). There is a potential risk that other governments could in the end feel forced to bail out a bankrupt government of an individual member country. There is a risk for pressures on the ECB of both direct (buying up the debt of a highly indebted country in the secondary market) and indirect bail-outs (setting lower interest rates than are motivated by price stability con- siderations). Finally, the recent "fiscal theory of price determination" emphasises the risk that the ECB will be unable to control inflation if fiscal policies are not sustainable (Canzoneri and Diba, 2001). The argument starts from the observation that solvency of the government requires the discounted value of future primary surpluses (including seigniorage revenue of the central bank) to match the outstanding real value of government debt. If fiscal policy violates this constraint, and monetary authorities do not relax their policy stance, solvency can only be maintained by an upward jump of the price level, which lowers the price of nominal government debt in terms of goods and thus reduces the real value of the debt.

\subsection{The present framework}

The fiscal rules in the $E U$ are determined mainly by the provisions in the Maastricht Treaty on the excessive deficit procedure (A rticle 104.3) and by the Stability and Growth Pact (SGP), which is embodied in two regulations of the $\mathrm{E}$ cofin Council and two resolutions of the $\mathrm{E}$ uropean Council (see, for example, B uti et al., 2001). ${ }^{7}$ The Treaty sets out the basic stipulations, whereas the SGP defines their operational content. The main rules are as follows:

- The Treaty sets a deficit ceiling (a reference value) of three percent of GDP for the actual government budget balance. $L$ arger deficits are considered "excessive" unless "the excess over the reference value is only exceptional and temporary and the ratio remains close to the reference value". The formal wording of this escape clause must be regarded as quite stringent, as all the conditions in it must in principle be fulfilled for it to apply (B alassone and Franco, 2001; B uti and Giudice, 2002). A ccording to the SG P, the exceptionality condition can refer either to "an unusual event outside the control of the Member State in question which has a major impact on the financial position of the general government" or to an "abrupt cyclical downturn". The formal decision on whether or not a deficit should be considered "excessive" is taken by the $\mathrm{E}$ cofin Council, acting on a recommendation from the Commission. A $n$ annual fall of real GDP of more than 2 percent should auto-

7 The E uropean Council consists of the heads of state or government of the $E U$ countries. 
matically be considered as "abrupt" and a fall of between 0.75 and 2 percent could be considered to be so after a discretionary judgement by the Council. The Council could also take into account the cumulative loss of output relative to past trends when deciding whether a member state has an "excessive deficit". If a member state does not take corrective action to eliminate an "excessive deficit", as recommended by the Council, it will be required to pay an annual interest-free deposit of 0.2-0.5 percent of GDP. If the "excessive deficit" persists, this deposit will be converted into a fine, which is distributed among the other member states.

- The Treaty also stipulates that gross government debt should not exceed 60 percent of GDP. If it does, the debt ratio should be decreasing "at a satisfactory pace". The wording must be interpreted to mean that government debt is not allowed to increase when it is above the 60 percent ceiling. Formally, no escape clause is associated with this stipulation, but there are no monetary sanctions in the case of violations.

- A ccording to the SG P, countries should aim for a "medium-term" budgetary position of "close to balance or in surplus". To ensure compatibility with this objective, there is a process of multilateral budgetary surveillance. EMU member states have to submit standardised stability programmes and non-EMU member states similar convergence programmes specifying budget targets. These programmes form the basis for the regular monitoring of the fiscal performance of individual countries by the Council, acting on recommendations of the Commission. In the case of a "significant divergence" of budgetary outcomes from targets, the Council can issue an early warning to a member state. A ccording to the stated principles of the Commission, it takes both cyclical developments and the risk of breaching the three-percent deficit ceiling into account when judging whether or not there is a "significant divergence" (E uropean Commission, 2002a). A downward deviation from the budget target due to the response of automatic stabilisers to unanticipated cyclical developments is not considered such a divergence for a country meeting the medium-term objective of "close to balance or in surplus", whereas it is for a country that does not fulfil this criterion and approaches the deficit ceiling.

One ambiguity in the SGP has concerned the "close to balance or in surplus" budget objective.
A common interpretation has been that this is a target for the cyclically adjusted budget balance (Balassone and Franco, 2001; Buti and Giudice, 2002; European Commission, 2002a). On this interpretation, it has been argued that the medium-term budget target should be set such as to provide a safety margin for both cyclical developments and unanticipated budgetary risks. Highdebt countries should, in addition, take into account the objective of reducing their government debt levels when setting their budget targets (E uropean Commission, 2002a). But, as noted in last year's EEAG report (EEAG, 2002), the SGP does not state explicitly that the medium-term objective refers to the cyclically adjusted balance, and the budget targets in the stability and convergence programmes have been stated in actual rather than in cyclically adjusted terms. R ecently, however, the Commission proposed that the medium-term budget objective should refer explicitly to the cyclically adjusted balance (European Commission, 2002b).

A $n$ important feature of the fiscal rules is that they attach greater importance to the current government budget balance (the net flow of receipts and expenditures) than to the stock of government debt. The monetary sanctions are related to violations of the deficit ceiling only but not of the debt criterion. The medium-term objective of "close to balance or in surplus" also refers to the current budget balance. However, as the long-run debt is determined by the cumulated sum of deficits over

\section{Figure 2.2}

The ACTUAL Budget Balance as A FUNCTION OF THE OUTPUT GAP

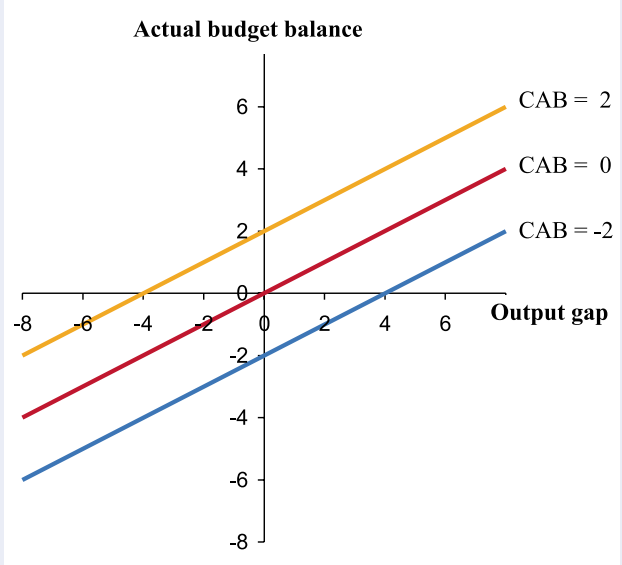

$\mathrm{CAB}=$ cyclically adjusted budget balance in percent of GDP 


\section{B ox 2.1}

\section{The cyclically adjusted budget balance}

Tax receipts in general and some government expenditures, such as unemployment benefits, vary automatically with the output and employment levels. To assess the underlying (structural) budgetary situation, one must therefore adjust the actual budget balance for the cyclical conditions. Computations of the cyclically adjusted budget balance require estimates of both the output gap, that is the extent to which actual output deviatesfrom the equilibrium (potential) level, and of the sensitivity of the budget balance to such deviations. Technically, the cyclically adjusted budget balance as a ratio of $\mathrm{GDP}, b_{c}$, is calculated as:

$b_{c}=b-\alpha g$,

where $b$ is the actual budget balance as a ratio of GDP, $g$ is the deviation of actual from equilibrium GDP as a ratio of equilibrium GDP, and $\alpha$ is the effect on the actual budget balance of a one percentage point increase in the output gap. The lines in Figure 2.2 show how the actual budget balance depends on the output gap and the cyclically adjusted budget balance. The cyclically adjusted balances are given by the intersections of the lines with the vertical axis. In booms, when the output gap is positive, the actual budget balance is more positive (less negative) than the cyclically adjusted balance. In recessions, when the output gap is negative, the actual budget balance is less positive (more negative) than the cyclically adjusted one. Provided that cyclical deviations are symmetrically distributed around equilibrium output, a given annual cyclically adjusted budget balance implies the same given average annual actual budget balance.

The largest problem in computing the cyclically adjusted budget balance is how to estimate the output gap. There exists no universally accepted way of doing this. Instead, different methods give different results and the estimates are often subject to large ex post revisions. One way of estimating equilibrium GDP for a country is to use purely statistical techniques to smooth the actual GD P series. This is typically done by applying a so-called Hodrick-Prescott filter. With this measure, one tries to strike a balance between obtaining a smooth time series for equilibrium (potential) GDP on the one hand and getting a reasonable fit to the actual data on the other hand.
The main problem with applying purely statistical techniques for estimating the output gap is that the estimates of equilibrium (potential) GDP are also influenced by actual G D P developments when there are persistent deviations from equilibrium, for example because of prolonged demand disturbances. This is an argument for instead using a production function approach, according to which equilibrium output is estimated on the basis of assessments of trends in total factor productivity and of the equilibrium levels of inputs of capital and labour. The most critical factor with this approach is probably how to assess the equilibrium employment rate. This is typically done on the basis of some kind of Phillips curve approach, where one tries to estimate the equilibrium unemployment rate consistent with a constant rate of inflation (NAIRU) or a constant rate of wage increase (NAWRU) (see, for example, Calmfors and U ddén Sonnegård, 2001).

Earlier, the Commission and the E cofin Council based their calculations of cyclically adjusted budget balances mainly on Hodrick-Prescott estimations. But the new Code of Conduct on the content and presentation of stability and convergence programmes, which was adopted by the Ecofin Council in 2001, stipulates that there should be a shift to a production function method and sets common standards for how the estimations should be made (European Commission, 2002a).

The estimates of how the actual budget balance reacts to variations in the output gap are usually based on assessments of the response of various tax receipts and government expenditures (see, for example, van den N oord, 2000). A s discussed in Section 1.1, these response parameters differ among countries, but an average value for $\alpha$ in the $E U$ is around 0.5 . This value is used in Figure 2.2. I t must be acknowledged, however, that estimated budget response parameters reflect average cyclical variations, so that the actual response in a specific situation characterised by atypical shocks may differ substantially from the average pattern. This is another serious problem when estimating cyclically adjusted budget balances. time, the budget balance objective implicitly defines a goal for long-run debt. If the "close to balance or in surplus" target is interpreted as a balanced cyclically adjusted budget, the implicit long-run target for government net debt is zero. ${ }^{8}$ In addition to this, recent Council Resolutions have suggested that the future strains on public finances from ageing populations may require

8 See the note to Table 2.7 even more ambitious targets (European Commission, 2002a).

A Ithough discretionary fiscal policy in the event of major cyclical disturbances are not explicitly ruled out by the Stability and G rowth Pact, the consensus seems to be that the medium-term target (the target for the cyclically adjusted balance) should provide room primarily for the automatic stabilisers to work (Buti and G iudice, 2002; E uropean Commission, 2002a). 
2.2 The case for revisions of the EU fiscal policy framework

The EU fiscal rules have been the subject of intensive discussion both in academic circles and in more popular contexts. A common criticism is the arbitrariness of the chosen deficit and debt ceilings as well as of the long-run budget balance and (implicit) net debt targets (see, for example, Buiter et al., 1993; or Wyplosz, 2002). Other types of criticism have pointed to the inappropriateness of focusing on gross rather than net government debt, which also takes into account government claims on the private sector or government net worth, which also includes government real assets (Buiter et al., 1993). A related argument suggests that it should be possible to finance government capital outlays through borrowing (a so-called "golden rule" of the type presently implemented in the UK; see, for example, B lanchard and G iavazzi, 2002).

With respect to macroeconomic stabilisation, which is our main focus here, two main objections have been raised. The first objection is that the fiscal rules may hamper stabilisation efforts in downswings (see, for example, Calmfors et al., 1997; Eichengreen and Wyplosz, 1998; Canzoneri and Diba, 2001; Swedish Government Commission on Stabilisation Policy in the EMU, 2002; or Wyplosz, 2002). This has been a common argument in the recent debate on the budget deficits in France, Germany, I taly and Portugal (de Grauwe, 2002; E conomist, 2002; Financial Times, 2002a,b,c). A second objection is that the fiscal rules provide insufficient incentives for fiscal restraint in booms by not rewarding such policies enough (B ean, 1998; Buti and Giudice, 2002). A s discussed in last year's EEAG report, the risk of fines if the deficit limit is violated in a recession may not influence government behaviour much in a boom, since the

Table 2.4 next recession may then appear very far-off and may even occur under another government, which the incumbent goverrnment may have no interest in helping. ${ }^{9}$ Such insufficient fiscal restraint in booms will increase output volatility (both directly and also indirectly because the scope for countercyclical fiscal policy in future recessions becomes smaller when the safety margin to the deficit ceiling is reduced ${ }^{10}$ ) and weaken the government budget balance over the cycle. Indeed, the current situation of Portugal, G ermany, France and I taly pro-

\footnotetext{
9 O ne should note the similarity between this argument and the argument that incumbent governments may choose deficit policies to constrain the possibilities of future governments of other political colours to favour their constituencies.

${ }^{10}$ See also the discussion in Section 1.1.
}

G eneral government cyclically adjusted fiscal balance as a percentage of G DP in the $E \mathbf{U}$ countries

\begin{tabular}{|l|rrrrrr|}
\hline & 1998 & 1999 & 2000 & 2001 & 2002 & 2003 \\
\hline B elgium & -0.6 & -0.9 & -1.1 & -0.3 & 0.2 & 0.2 \\
D enmark & 0.5 & 2.5 & 1.3 & 2.6 & 2.1 & 2.1 \\
G ermany & -1.9 & -1.4 & -1.9 & -2.8 & -3.3 & -2.4 \\
G reece & -1.9 & -1.6 & -1.8 & -2.1 & -1.7 & -1.8 \\
Spain & -2.6 & -1.5 & -1.4 & -0.7 & -0.1 & -0.2 \\
France & -2.6 & -2.0 & -2.1 & -2.0 & -2.7 & -2.8 \\
Ireland & 1.9 & 0.8 & 2.5 & 0.2 & -1.4 & -0.8 \\
Italy & -3.0 & -1.9 & -2.1 & -2.4 & -1.8 & -1.6 \\
N etherlands & -1.9 & -1.2 & -0.6 & -1.2 & -0.6 & 0.0 \\
A ustria & -2.4 & -2.5 & -2.5 & 0.0 & -1.6 & -1.4 \\
Portugal & -3.0 & -3.0 & -4.0 & -4.3 & -3.0 & -1.9 \\
Finland & -0.4 & 0.3 & 3.8 & 3.8 & 3.7 & 3.3 \\
Sweden & 2.3 & 0.6 & 2.1 & 4.2 & 1.3 & 1.3 \\
U nited K ingdom & -0.3 & 0.8 & 1.2 & 0.7 & -0.6 & -0.9 \\
\hline G D P-weighted average & -1.7 & -1.0 & -1.0 & -1.2 & -1.6 & -1.4 \\
U nweighted average & -1.1 & -0.8 & -0.5 & -0.3 & -0.7 & -0.5 \\
\hline
\end{tabular}

Source: E uropean Commission (2002c). 
vide good examples of how such insufficient fiscal restraint in the 1999-2000 upswings have created deficit problems in the subsequent recession (see Tables 2.3 and 2.4).

A very different type of critique has focused on the difficulties of applying the fiscal rules in concrete situations. The argument is that it will be difficult in practice to fine a member state that exceeds the deficit ceiling (Calmfors et al., 1997; U hlig, 2002). Such actions are likely to arouse serious political conflicts among the member states. It may also be difficult to explain to the general public that the proper way of handling a deficit situation in a country is to incur extra expenditures in the form of fines to the $E$ uropean neighbours. The decision of the Council in early 2002 to avoid giving G ermany and Portugal early warnings for the deviations relative to the agreed budget targets, despite a recommendation from the Commission to do so, provides a clear illustration of the difficulties of applying the rules in practice. So does the present situation, in which the budgetary problems in some member states have led to demands that the SG P should be flouted.

The objections we have summarised all raise highly relevant issues. B ut it is also clear that any fiscal rule has to reflect a difficult trade-off between what would be theoretically optimal and simplicity. A rule must be simple to facilitate monitoring and enforcement (Kopits and Symansky, 1997). Simplicity is also required if the rule is to be understood by the general public. 0 therwise the rule will not command the legitimacy necessary for it to be respected by policy makers and be sustainable in the long run. Simplicity of the rules is probably of extra importance in the context of the $E U$, which has often been accused of being too technocratic. In our view, the provisions in the M aastricht Treaty and the SG P do, on the whole, represent a reasonable trade-off between conflicting demands and have played a very useful role for strengthening fiscal discipline. The rules have become common knowledge and are a useful common benchmark for fiscal policy in the member countries.

A the same time, it should be acknowledged that the fiscal rules were instituted in a specific historic situation. There was an urgent need for reversing the trend of rapidly accumulating government debt and to quickly establish credibility for the new currency in its initial phase. Once the monetary union has been shown to work, it might be possible to refine the fiscal rules more than was possible in the 1990s.

One counter argument is that such modifications might undermine the credibility of any common EU fiscal rules by creating the impression that they can always be revised in response to the existing situation. These are crucial considerations, but it must also be recognised that if the rules are perceived as being too inflexible, they will lose their legitimacy. The likely consequence of this is either that the rules will be constantly bent or that they will at some point be abandoned altogether.

A reasonable conclusion is that one should look for possible modifications of the fiscal rules that enhance their effectiveness and legitimacy without changing their main character. As argued in last year's EEAG report (EEAG, 2002), there is an obvious case in favour of formulating the mediumterm budget balance objective explicitly in cyclically adjusted terms in order to allow the automatic stabilisers to work. We therefore fully endorse the Commission's recent proposals on this (E uropean Commission, 2002b). In addition, as discussed in Section 1, there are strong arguments for allowing discretionary fiscal policy action, that is variations in the cyclically adjusted budget balance, in some situations. These could involve large asymmetries in cyclical developments among the euro countries or large common macroeconomic disturbances where monetary policy needs to be supported by fiscal policy.

It would not be appropriate, however, to formulate the deficit ceiling in terms of the cyclically adjusted budget balance rather than in terms of the actual balance. The obvious reason is that there is no unique way of adjusting the actual budget balance for cyclical factors. Different methods of calculating the cyclically adjusted balance give different results, as discussed in B ox 2.1. In addition, the calculations are frequently revised ex post. O ne cannot base sanctions on a measure that is so open to different interpretations.

A s argued in Box 2.2, there is a strong case in all EU member states for trying to attain average budget outcomes of "close to balance or in surplus", or even more ambitious budget goals, over the coming decade(s), because of the future strains on government finances due to demographic develop- 
B ox 2.2

\section{L ong-run government debt}

A common criticism of the Stability and G rowth Pact is that the medium-term budget target of "close to balance or in surplus" is arbitrary. It is often claimed to be too ambitious as it implies that net government debt will over time converge to around zero (see, for example, de G rauwe, 2002; or Walton, 2002).

It is true that theoretical analysis does not give much guidance on what is an optimal level of long-run government debt, although it points to various important aspects (K ell, 2001; Wyplosz, 2002):

- From the point of view of minimising long-run tax distortions that reduce social efficiency, a low debt level (or a positive net financial position) for the government is desirable.

- On the other hand, to the extent that households are credit-constrained, social welfare is increased if governments can borrow on their behalf.

- Intergenerational equity is affected by the level of debt, since this influences how consumption possibilities are distributed across generations.

N one of these considerations have played a major role in the choice of budget targets (and thus implicitly also of debt targets) in the SG P. Instead, as discussed in Section 2, more pragmatic considerations relating to longrun fiscal sustainability have dominated. The aim has been to lower debt to prudent levels in order to reduce the risks of inflation and high interest rates. In such a perspective, the future strains on government budgets that can be expected from ageing populations (due both to higher pension payments and higher health-related government expenditures) become of paramount importance. Table 2.5 (p. 60) presents estimates by the E conomic and Financial Committee in the $\mathrm{EU}$ of future expenditure increases due to demographic developments. A s can be seen, such projections indicate an average increase in age-related government expenditures of 6.2 percent of GDP in the EU countries between 2000 and 2040. The estimated increases are largest in Greece, the Netherlands, Spain, and Finland (7-13 percent of GDP), but much smaller in the UK, Italy, and Sweden (0- 4 percent of GDP). Needless to say, the calculations are based on a number of uncertain assumptions, for example regarding labour force participation and unchanged policies (implying, for example, substantial reductions of pension replacement rates in I taly and the $U \mathrm{~K}$ ). The projections do not take into account that there is some reduction in other agerelated expenditures, like for childcare. The calculations are also before tax, so that they do not measure the net effects on the government budget balance. Still, the calculations illustrate clearly that ageing populations will result in large budgetary pressures.
Further reductions of government debt, and thus also of interest payments, is one way of accommodating the tendencies to deteriorating primary budget balances (the balances excluding interest payments). Table 2.6 (p. 61) is an attempt to illustrate this in a very simplified manner. Column 1 shows the 2001 primary balances. Column 2 shows the primary surpluses necessary to service interest payments if the debt-to-GDP ratio were to stay at the 2001 level. The other columns show how much lower primary surpluses need to be from 2020 and onwards, as compared to this benchmark, under various assumptions on total budget balances (including interest payments) in the period 2001-20 if the debt-to-GDP ratio is to be held stationary after this period. The assumptions that fiscal policies can be characterised by various assumptions on the total budget balance up to 2020 and that the debt levels after that are stabilised at the 2020 level are arbitrary, but serve as a crude illustration of the extent to which the future demands on primary budget surpluses are affected by present policies.

O ur calculations illustrate that the future reductions in required primary surpluses that follow from present policies (and also from more ambitious ones) are small relative to the budgetary strains imposed by ageing populations. The average reduction in required primary surpluses from the debt reduction associated with zero budget balances in 2001-20 as compared with present debt levels is only 0.7 percent of GDP (1.2-0.5). Budget deficits of 1.5 percent of GDP instead of zero balance would yield a reduction of the average required primary surplus by only 0.3 percent of G DP (1.2-0.9). A total budget surplus in 2001-20 of 3 percent of G D P implies a reduction of the average required primary balance by 1.5 percentage points, allowing a small average primary deficit after 2020. The effects are of different magnitude for different countries, the largest effects occurring for the countries with the largest initial debt levels (I taly, B elgium and G reece).

In the perspective of Table 2.6, it is difficult to claim that the present "close to balance or in surplus" target is too ambitious. The projected increase in agerelated expenditures is a strong argument against relaxing the budgetary objectives, for example by adopting a "golden rule", according to which government investment can be financed through borrowing. $R$ ather, if anything, there appears to be a strong case for sharpening the medium-term fiscal objectives in most countries as a complement to pension reform. ments. In this situation, it would seem very unwise to loosen the budget objectives, for example through the adoption of a so-called "golden rule", which would allow borrowing for government investment or other selected government expenditures believed to promote growth. The arguments against a golden rule are developed further in B ox 2.3. 


\section{B ox 2.3}

\section{The golden rule}

The "golden rule" in public finance is the notion that borrowing should be allowed for public investment. Such a golden rule for both the federal government and the states is formally enshrined in the German constitution. M ore recently, the U K has adopted such a rule, according to which deficit financing of government net investment is allowed, provided that the overall government debt is kept at prudent levels (at present defined as a ratio of net government debt to GDP below 40 percent) (see Buiter, 2001; or K ell, 2001). In the discussion of the Stability and G rowth Pact, it has been argued that the present medium-term objective of "close to balance or in surplus" should be replaced by a golden rule, which would also require a redefinition of the deficit ceiling in the Treaty (see, for example, B lanchard and G iavazzi, 2002).

The crucial issue when judging the future budgetary consequences of a public investment project is whether it generates a cash flow accruing to the general government, whose (appropriately measured) present value is at least equal to its financial costs for the government. If this is the case, deficit financing of public investment does not cause a deterioration of future budget balances and does not require any future rises in tax rates or cuts in spending. 0 therwise, the structural deficit will be worsened to the extent that future additions to tax revenue fall short of interest costs of the additional debt.

In principle, the statements above could be turned into a test to discriminate among different public investment projects. A ccording to this test, projects meeting a minimum cash-flow requirement could be excluded from the deficit figure subject to the rules of the SG P. Government borrowing would be disallowed only for the costs of those projects failing the test.

These considerations show that a "golden rule" should never be applied mechanically. $\mathrm{R}$ ather, it should always be made conditional on an assessment of the future financial flows from public investment. This is because nothing requires the public sector to undertake projects only if they satisfy the test specified above. The provision of public goods requiring public investment may well be motivated by their utility value, independent of whether or not it can generate a positive cash flow. M any projects may be highly desirable, yet require tax financing.

B ut even such a stricter and sounder golden rule would run into a number of theoretical and practical objections that strongly discourage its application. First and foremost, it is very difficult to assess future revenues accruing to the general government. Such an assessment is necessarily based on arbitrary assumptions, and these assumptions are unavoidably open to manipulation. Typically, one should take both direct and indirect public revenues into account. A n example of the latter is any increase in tax revenue due to incomes that would not be generated in the absence of public investment. H owever, proponents of a particular project, and groups benefiting directly from it, will have strong opportunistic motives to inflate the estimates of the indirect effects. A Iso, as amply documented, inadequate budgeting and implementation of public investment projects typically result in cost revisions, systematically reducing net cash flows well below the initial estimates. Moreover, the classification of public expenditures between "current expenditures" and "investment" is quite ambiguous. For example, should spending on public education be viewed as public investment in human capital? A nd why should tax cuts that stimulate private investment be treated differently from direct government investment? A dopting a golden rule will clearly create a strong incentive to reclassify many items in the budget, with no other purpose than to circumvent the Stability and G rowth Pact.

Second, suppose that the public sector can accurately predict cash flows, and is able to commit itself to extremely disciplined control procedures. Even so, it is quite difficult to identify the correct interest costs. For instance, a large programme of public investment could change the equilibrium interest rate in the economy: using interest rates prevailing before the implementation of the program would therefore not be appropriate.

The recent revival of the debate on the golden rule may actually divert attention from a deeper issue. Fiscal retrenchment implemented by several countries in the euro area throughout the 1990s resulted in large cuts in public capital expenditure. A $s$ is well understood, the interest groups fighting cuts in public investment are not as strong and vocal as the interest groups opposing cuts in current transfers programs. Public capital investment tends to have diffuse effects and - more importantly - tends to benefit both current and future generations.

Intergenerational redistribution via public capital is a theme that is often forgotten in the political debate. A n inefficiently low level of public infrastructure, and a low quality, can harm future generations at least as much as higher future taxes financing present transfers. In many areas, a reduced presence of the public sector has crowded in private investment, substituting private for public capital. But especially for infrastructure, there is a widespread feeling that development and maintenance have been falling below efficient levels. Is this an argument to relax budget goals? What is called into question is not really budget discipline - but the political priorities in the national budget process as well as budget choices at the E uropean level. If the investment in infrastructure is too low, which creates large welfare costs for current and future generations, governments can change spending plans or find proper ways to finance additional spending. In this respect, it should be kept in mind that deficit financing of in- 
continued B ox 2.3

vestment generates future interest payments - payments that are avoided if investment is tax-financed. So, requiring tax financing does not impose any additional burden on taxpayers in the long run. It does, however, give rise to redistribution effects in favour of future generations in the short and medium run.

In principle, the golden rule could be defended as a way to make future generations sustain the costs of infrastructure projects that will also benefit them. By the same token, it is well known that efficiency (taxsmoothing) arguments suggest the desirability of deficit financing at an early stage of development: countries starting with a low capital stock have a large need to build infrastructure, and should therefore be given the financial flexibility to do so. While all this is true, it should not be forgotten that what motivated the Stability and G rowth Pact is exactly the argument according to which sound economic principles are seldom followed in the actual budget process.

R ecently, a common misinterpretation of public finance principles has been that there is a case for excluding military spending from the budget objectives according to the SGP. It is true that the tax smoothing principle implies that any temporary upsurge in military spending should be financed by borrowing, and not by increasing taxes, because this avoids welfare-decreasing variations in private consumption. $B$ ut in the case of $E$ urope, those who believe in a larger military role for the $E U$ advocate a permanent (rather than temporary) step-up of defence spending. While the choice of increasing military spending is a political one - and there is by no means an agreement on whether and how much the EU should change its course on this matter - there is no economic argument for deficit financing.
We view the existing EU fiscal rules as a valuable institutional framework that should be exploited, because other alternatives will involve new and high set-up costs. This is an argument of history dependence. Given that the present framework is there, there is a strong case for continuing to build on it. This requires that the credibility of the fiscal rules is maintained. In particular, any changes in the fiscal rules must not be perceived as giving in to claims from member states that have current difficulties.

R ecent proposals of the E uropean Commission aim at making the fiscal rules more flexible through a reinterpretation of the Stability and G rowth Pact, which would not require any Treaty changes (E uropean Commission, 2002b). The proposals focus mainly on the medium-term budget target, but not on the deficit ceiling. In our view, this is insufficient and potentially harmful. More fundamental changes, involving a revision of the Maastricht Treaty, are desirable.

The most important stipulations on fiscal policy are those that refer to excessive deficits. The possibility of sanctions has much stronger incentive effects than other stipulations and forms the backbone of the fiscal rules. So, we believe that more of the discussion should focus on this aspect. We see two desirable changes in the excessive deficit procedure:

- To condition the scope for stabilisation policy in downswings on the level of debt, so that lowdebt countries are allowed to run larger deficits than high-debt countries.

- To depoliticise the decision-making process that establishes whether or not individual countries have violated the rules.
Table 2.5

Projected increases in age-related public expenditures in the E U countries in percent of G D P, 2000 - 2040

\begin{tabular}{|l|cccc|}
\hline & Pensions & $\begin{array}{c}\text { Health care } \\
\text { expenditures }\end{array}$ & $\begin{array}{c}\text { Long-term care } \\
\text { expenditures }\end{array}$ & Total \\
\hline A ustria & 3.8 & 1.6 & 0.7 & 6.2 \\
B elgium & 3.7 & 1.3 & 0.7 & 5.7 \\
Denmark & 3.6 & 0.7 & 1.8 & 6.1 \\
Finland & 4.7 & 1.2 & 1.6 & 7.5 \\
France & 3.8 & 1.2 & 0.4 & 5.4 \\
G ermany & 4.8 & 1.4 & na & $(6.2)$ \\
G reece & 11.2 & 1.5 & na & $(12.7)$ \\
Ireland & 3.6 & 1.9 & 0.1 & 5.6 \\
Italy & 1.9 & 1.4 & 0.3 & 3.6 \\
L uxembourg & 2.2 & na & na & $(2.2)$ \\
N etherlands & 6.2 & 1.0 & 1.8 & 8.9 \\
Portugal & 4.0 & 0.6 & 1.6 & 6.3 \\
Spain & 6.6 & 1.5 & na & $(8.1)$ \\
Sweden & 2.4 & 0.9 & 0.6 & 3.9 \\
U nited K ingdom & -0.5 & 0.8 & 0.0 & 0.3 \\
\hline U nweighted average & 4.1 & $(1.2)$ & $(0.9)$ & $(6.2)$ \\
\hline Note: Figures are given in parenthesis when there are missing data. & \\
\hline
\end{tabular}

Source: Table II.7, E uropean Commission (2002a). 
Table 2.6

$R$ equired primary surpluses in the $\mathrm{E} U$ countries to stabilise the debt ratio after 2020 under various assumptions (debt ratios in paranthesis)

\begin{tabular}{|c|c|c|c|c|c|c|c|}
\hline \multirow[b]{2}{*}{ Country } & \multirow{2}{*}{$\begin{array}{l}\text { Current cyclically } \\
\text { adjusted primary } \\
\text { surplus (2001) }\end{array}$} & \multirow{2}{*}{$\begin{array}{c}\text { R equired primary } \\
\text { surplusat } \\
\text { current debt } \\
\text { level (2001) }\end{array}$} & \multicolumn{5}{|c|}{$\begin{array}{l}\text { R equired primary surplus at various annual total budget } \\
\text { balances } 2001-2020\end{array}$} \\
\hline & & & -3 & -1.5 & 0 & 1.5 & 3 \\
\hline A ustria & -0.1 & $1.2(61.7)$ & $1.3(66.0)$ & $0.9(46.3)$ & $0.5(26.6)$ & $0.1(\quad 6.9)$ & $-0.2(-12.8)$ \\
\hline Belgium & 6.2 & $2.1(107.5)$ & $1.7(87.4)$ & $1.3(67.5)$ & $0.9(47.6)$ & $0.5(27.7)$ & $0.2(7.7)$ \\
\hline Germany & 0.7 & $1.2(59.8)$ & $1.2(63.4)$ & $0.9(44.0)$ & $0.5(24.7)$ & 0.1 ( 5.3) & $-0.3(-14.0)$ \\
\hline D enmark & 6.7 & 0.9 ( 44.5$)$ & $1.2(62.6)$ & $0.8(42.0)$ & $0.4(21.4)$ & 0.01 & $-0.4(-19.8)$ \\
\hline Spain & 2.4 & $1.1(57.2)$ & $1.2(59.2)$ & $0.8(40.4)$ & $0.4(21.7)$ & 0.11 & $-0.3(-15.7)$ \\
\hline Finland & 6.3 & $0.9(43.6)$ & $1.2(60.1)$ & $0.8(40.0)$ & $0.4(19.8)$ & $0.0(-0.3)$ & $-0.4(-20.4)$ \\
\hline France & 1.5 & $1.1(57.2)$ & $1.3(65.0)$ & 0.9 (45.1) & $0.5(25.2)$ & 0.1 ( 5.3) & $-0.3((-14.5)$ \\
\hline U nited $\mathrm{K}$ ingdom & 3.0 & $0.8(39.0)$ & $1.1(55.8)$ & $0.7(36.2)$ & $0.3(16.6)$ & $-0.1(-3.0)$ & $-0.4(-22.6)$ \\
\hline G reece & 5.5 & $1.9(99.7)$ & $1.7(87.3)$ & $1.3(66.9)$ & 0.9 (46.6) & 0.5 ( 26.2) & 0.1 ( 5.9) \\
\hline I reland & 1.4 & $0.7(36.6)$ & $0.8(38.4)$ & $0.5(23.2)$ & $0.2(8.0)$ & $-0.1(-7.2)$ & $0.4(-22.5)$ \\
\hline Italy & 4.9 & $2.1(109.4)$ & $1.8(93.0)$ & $1.4(72.5)$ & $1.0(52.0)$ & 0.6 ( 31.5) & 0.2 ( 11.0$)$ \\
\hline L uxembourg & 3.8 & $0.1(5.5)$ & $0.6(32.5)$ & $0.3(16.9)$ & $0.0(1.3)$ & $-0.3(-14.3)$ & $-0.6(-29.9)$ \\
\hline Netherlands & 3.1 & $1.0(53.2)$ & $1.2(60.0)$ & $0.8(40.8)$ & $0.4(21.6)$ & $0.0(\quad 2.4)$ & $-0.3(-16.9)$ \\
\hline Portugal & 0.1 & $1.1(55.6)$ & $1.1(56.9)$ & $0.8(38.5)$ & $0.4(20.1)$ & 0.01 & $-0.3(-16.6)$ \\
\hline Sweden & 7.6 & $1.1(56.0)$ & $1.3(68.0)$ & $0.9(47.4)$ & $0.5(26.9)$ & $0.1 i$ & $-0.3(-14.3)$ \\
\hline U nweighted average & 3.5 & $1.2(59.1)$ & $1.2(63.7)$ & $0.9(44.5)$ & $0.5(25.3)$ & $0.1(\quad 6.2)$ & $-0.3(-13.0)$ \\
\hline \multicolumn{8}{|c|}{$\begin{array}{l}\text { Note: Column } 1 \text { gives the current (2001) primary budget balance (the budget balance excluding interest payments). Column } 2 \text { gives the } \\
\text { primary balance necessary to stabilise government debt at its current (2001) value (with the debt level in parenthesis). The subsequent } \\
\text { columns show the primary balances necessary to stabilise government debt from } 2020 \text { and onwards under various assumptions on the } \\
\text { total annual budget balance (including interest payments) in } 2001 \text { - } 2020 \text {. The stationary debt levels are given in parenthesis. A nnual } \\
\text { real G D P growth for each country in } 2001 \text { - } 2020 \text { is assumed to be the same as the average for } 1985-2001 \text {. A nnual inflation in } 2001-2020 \\
\text { is assumed to be } 2 \text { percent. From } 2020 \text { and onwards, nominal G D P growth in all countries have been set equal to the average real G DP } \\
\text { growth for all EU countries in } 1985 \text { - } 2001 \text { plus } 2 \text { percent. The nominal interest rate is assumed to be } 2 \text { percentage points higher than the } \\
\text { nominal growth rate. }\end{array}$} \\
\hline
\end{tabular}

Source: Columns 1 and 2: E uropean Commission. The other columns: computations by EE AG group and José M auricio Prado.

2.3. A $n$ enhanced role for the debt level as a fiscal policy criterion

A s discussed in the previous section, the current EU fiscal rules assign more importance to the current budget balance than to the debt level. This can be criticised on the grounds that the amount of debt is a more relevant variable if one is concerned about long-run fiscal sustainability and price stability (B eetsma, 2001; Canzoneri and Diba, 2001). O $n$ the other hand, the current budget situation is likely to be a better predictor of future budget outcomes than the historic debt level (Perotti et al., 1998). From a more practical standpoint, the focus on the budget balance rather than on debt in the $M$ aastricht Treaty was probably motivated to a large extent by the great dispersion in debt levels among the prospective entrants to EMU (see Table 2.2), which made it difficult to use debt as a convergence criterion if one wanted to achieve the joint objectives of giving everyone a reasonable chance of qualifying and disciplining fiscal behaviour. A nother motivation was the larger ambiguities associated with measuring the debt level than the current budget balance.

We find it a reasonable argument that the present fiscal rules do not allow countries with low govern- ment debt to reap the full benefits of this situation (Pisani-Ferry, 2002). Indeed, a main benefit of low government debt should be to enhance the room for manoeuvre in stabilisation policy by allowing larger deficits in recessions than would otherwise be possible (Swedish G overnment Commission on Stabilisation Policy in the E MU, 2002). This can be seen as a corollary to the common argument that a track record of low inflation for a central bank should enhance the scope for interest rate cuts in a downswing.

A ccording to the present fiscal rules, there is an association between the debt level and the scope for stabilisation policy, but it is implicit rather than explicit. One association is the stipulation that countries with a debt ratio higher than 60 percent are not allowed to increase it, which may be a more binding constraint for these countries than the deficit ceiling, whereas there is no such stipulation for countries with lower debt ratios ( $B$ alassone and M onacelli, 2000). Table 2.7 shows the maximum deficits at various debt levels and growth rates consistent with the condition that the debt ratio must not increase. The debt change stipulation has the peculiar implication that it constrains the size of deficits more the closer the debt ratio is to the 
Table 2.7

\section{D eficit levels consistent with a stable debt-to-G D P ratio}

\begin{tabular}{|c|c|c|c|c|c|}
\hline & \multicolumn{5}{|c|}{ D ebt-to-G D P ratio } \\
\hline $\begin{array}{l}\text { Nominal } \\
\text { growth rate }\end{array}$ & 60 & 70 & 80 & 90 & 100 \\
\hline $3 \%$ & 1.7 & 2.0 & 2.3 & 2.6 & 2.9 \\
\hline $4 \%$ & 2.3 & 2.7 & 3.1 & 3.5 & 3.8 \\
\hline $5 \%$ & 2.9 & 3.3 & 3.8 & 4.3 & 4.8 \\
\hline \multicolumn{6}{|c|}{$\begin{array}{l}\text { Note: The change in the debt-to-G D P ratio, } d \text {, is given by } \\
\Delta d_{\mathrm{t}}=-b_{\mathrm{t}}-\phi /(1+\phi) d_{\mathrm{t}-1} \text {, where } b \text { is the budget balance in } \\
\text { percent of GDP and } \phi \text { is the rate of growth of nominal } \\
\text { GDP. The deficits in the table are obtained by setting } \\
\Delta d_{\mathrm{t}}=0 \text { and solving for } b_{\mathrm{t}} \text {. }\end{array}$} \\
\hline
\end{tabular}

Source: Calculations by E EA G group.

60 percent reference value. For example, assuming a 3 percent nominal growth rate, the maximum deficit is 2.9 percent of G DP at a 100 percent debt ratio, whereas it is only 1.7 percent at a 60 percent debt ratio. This follows from the fact that nominal GDP growth automatically tends to reduce the debt-to-G D P ratio less the lower this ratio, requiring lower deficits if the ratio is not to increase. However, it is not clear how much emphasis is in practice likely to be put on the debt change stipulation. A gainst the letter of the Treaty, it was ignored as a convergence criterion for Germany, which violated it at the start of EMU. Nor has the debt change criterion received much attention in the recent discussion, although Italy is likely to have violated it in 2002 and Germany is likely to do so in 2003 (see Table 2.2).

There is also an indirect association between the scope for stabilisation policy and the debt level, as low debt implies lower interest payments. For example, assuming a 4 percent average interest rate on government debt, a reduction of the debt ratio from 50 percent to 25 percent of GDP would reduce interest payments as a ratio of GDP by 1 percentage point (from 2 to 1 percent). Ceteris paribus this would improve the total budget balance. This assumes, however, that the lower interest payments have not been offset by a deterioration of the primary budget balance (the budget balance excluding interest payments) through tax cuts or expenditure increases. O ne could also argue that there should be a positive association between low debt and strong government budget positions because low debt can only have been achieved through small deficits or through surpluses in the past, and budget situations tend to exhibit a high degree of persistence (Perotti et al., 1998). A ccording to this argument, a low debt level would be associated with a high probability of a strong current government budget position, which gives a large cyclical safety margin in a downswing. But on the other hand, we know from empirical studies of the determinants of the government budget balance that high debt is conducive to low deficits (high surpluses), as it creates pressure for adjustment (see, for example, von $\mathrm{H}$ agen et al., 2002).

Finally, the Council is likely in practice to take into account the debt position of a country when judging whether the escape clause allowing violations of the deficit ceiling in certain situations can be invoked, even if this is not formally stated (see Section 2.1).

The recent Commission proposals on reinterpreting the SGP involve a greater emphasis on debt (E uropean Commission, 2002b). First, it is argued that the debt change criterion should be taken seriously and that breaches of it should trigger the excessive deficit procedure. Second, the Commission has proposed that member states with debt lower than 60 percent of GDP should be given the possibility of small temporary deviations from the "close to balance or in surplus" target for the cyclically adjusted budget balance if these deviations derive from a "large structural reform" aiming at promoting growth. A third proposal is that "small deviations of a longer-term nature" from the "close to balance or in surplus" objective could also be envisaged for member states with debt ratios "well below the 60 percent reference value".

We see two major problems with the Commission's proposals. One is the increased complexity of the rules and the amount of discretionary judgements introduced. A nother problem is that loosening the medium-term fiscal objective without changing the deficit ceiling reduces the safety margins and thus increases the risk that the ceiling is breached.

In our view, a better plan for reforming the fiscal framework should instead focus on the deficit ceiling directly. There should be a clear and transparent rule. $O$ ne possibility would be to condition the deficit ceiling explicitly on the debt level, allowing low-debt countries to run larger deficits in downswings than high-debt countries. More precisely, low-debt countries could be allowed to run larger budget deficits than three percent of GDP. Such a Treaty revision would have several advantages. 
1. The scope is widened for low-debt countries to pursue expansionary fiscal policy in a downswing.

2. The incentives for fiscal restraint in general are enhanced if the returns to such policies in the form of a greater scope for stabilisation policy in downswings become higher and more visible.

3. The stronger incentives for fiscal discipline imply smaller risks of procyclical policies in booms.

4. To the extent that the advantages of fiscal discipline become larger, the legitimacy of the fiscal rules and thus their credibility would be enhanced.

Technically, a link between the deficit ceiling and the debt level could be established in several ways. O ne could simply stipulate different deficit ceilings for different debt intervals. O ne proposal, which raises the deficit ceiling for low-debt countries but leaves it unchanged for high-debt countries, is given in the first column of Table 2.8 (see also Calmfors and Corsetti, 2002a,b). A n alternative would be a scheme like the one in the second column, according to which the rises in the deficit ceiling for low-debt countries are matched by reductions for high-debt countries. The latter proposal may appear less politically realistic, but it could perhaps be made more attractive if it is linked to a formal abolition of the debt change criterion for the countries exceeding the 60 percent debt-to-

\section{Table 2.8}

Possible ways of conditioning the deficit ceiling on the debt ratio

\begin{tabular}{|c|c|c|c|}
\hline \multirow{2}{*}{$\begin{array}{l}\text { D ebt ratio } \\
\text { (percent of G DP) }\end{array}$} & \multicolumn{3}{|r|}{ D eficit ceiling ( percent of G D P) } \\
\hline & Rule 1 & Rule 2 & Countries in the debt range \\
\hline$>105$ & 3.0 & 0.5 & I taly \\
\hline $95-105$ & 3.0 & 1.0 & B elgium, G reece \\
\hline $85-95$ & 3.0 & 1.5 & \\
\hline $75-85$ & 3.0 & 2.0 & \\
\hline $65-75$ & 3.0 & 2.5 & \\
\hline $55-65$ & 3.0 & 3.0 & $\begin{array}{l}\text { Portugal, France, G ermany, A ustria, } \\
\text { Bulgaria }\end{array}$ \\
\hline $45-55$ & 3.5 & 3.5 & Netherlands, Sweden, Spain, H ungary \\
\hline $35-45$ & 4.0 & 4.0 & $\begin{array}{l}\text { Ireland, U K, Finland, D enmark, Slovak } \\
\text { R epublic, Poland }\end{array}$ \\
\hline $25-35$ & 4.5 & 4.5 & Czech R epublic, Slovenia \\
\hline$<25$ & 5.0 & 5.0 & $\begin{array}{l}\text { Luxembourg, E stonia, L atvia, L ithuania, } \\
\text { Romania }\end{array}$ \\
\hline \multicolumn{4}{|c|}{$\begin{array}{l}\text { Note: A ccession countries in italics. These countries have been classified above } \\
\text { according to their debt ratios in } 2002 \text {. The incumbent EU member states have been } \\
\text { classified according to predicted debt ratios in } 2003 \text {. }\end{array}$} \\
\hline
\end{tabular}

Source: See Tables 2.2 and 2.9 .
GDP reference value. A lower deficit ceiling for these countries would serve the same purpose as the debt change criterion, but do away with the anomaly that present rules formally require lower maximum deficits for high-debt countries the closer their debt ratio is to the 60 percent value.

A major advantage of such discontinuous "ladders" of deficit ceilings as shown in Table 2.8 is that they provide a strong incentive for fiscal discipline in normal times as well as in booms by allowing countries to move to categories with a higher "status". Even if it is future governments that would get the advantage of a greater scope for stabilisation policy in recessions, it becomes much more visible to the general public that the incumbent government has made an investment that represents a future gain. ${ }^{11}$

A $n$ alternative set-up would be to retain the present three-percent deficit ceiling, but allow countries to use extra-budgetary stabilisation funds in downswings that are not formally included under the deficit ceiling. Such so-called "rainy-day funds" exist in many U S states and C anadian provinces as a cushion against unforeseen contingencies (Kopits and Symansky, 1997; Knight and Levinson, 1999; M CG ranahan, 1999; Hemming and Kell, 2000) and have been discussed in the E uropean context by $B$ uti and Giudice (2002) and Buti et al. (2002). A system with such funds could be constructed so as to mimic debt-deficit links of the type indicated by R ule 1 in Table 2.8. Countries with debts below given thresholds would be allowed to establish such funds and to draw maximum pre-specified amounts from them in recessions, in addition to running deficits in the normal budget up to three percent of GDP. One possibility is to let countries with government debt ratios below certain thresholds establish the stabilisation funds immediately through borrowing, which would

\footnotetext{
11 In addition, one can, of course, also institute a rule that a procyclical loosening of fiscal policy in a boom represents a violation of the budgetary requirements in the SGP, as proposed by the Commission (European Commission, 2002b). But one would expect our pro posal to have more bite, as it does not require discretionary decision-making.
} 
increase gross (but not net) government debt, or by transferring claims on the private sector to them. A nother more demanding option is to let low-debt countries build up the funds over time by channelling government surpluses into them in good times.

A system of extra-budgetary "rainy-day-funds" could formally maintain the three-percent ceiling as the point of reference. It would "lock in" the assets put in the funds by earmarking them only for stabilisation of output and employment in recessions. A rguably, however, a system of extra-budgetary funds is less transparent than a system that explicitly conditions the deficit ceiling on the debt level.

H ow would the accession countries be affected by rules that explicitly condition the deficit ceiling on the debt level? The accession countries have on average much lower government debt than the present EU member states (see Table 2.9). Therefore, a rule that relates the maximum deficit to the debt level gives them more scope for stabilisation policy in downswings than the incumbent member states. This could be motivated to the extent that the accession countries are likely to be exposed to larger cyclical swings, as they are in a phase of transition to developed market economies. It is true that this could al so involve risks that serious budgetary imbalances develop, as there are some tendencies to (see Table 2.9). But on the other hand the accession countries will also have a stronger tendency to reduce their debt ratios than the present EU member states because they will have higher nominal GDP growth. This is the consequence of both higher convergence-driven real

Table 2.9

The fiscal position of accession countries in 2002

\begin{tabular}{|l|c|c|}
\hline & $\begin{array}{c}\text { G ross government debt } \\
\text { asa percentage } \\
\text { of G D P }\end{array}$ & $\begin{array}{c}\text { G eneral government actual } \\
\text { fiscal balance in percent } \\
\text { of G D P }\end{array}$ \\
\hline Bulgaria & 58.1 & -0.8 \\
Czech R epublic & 25.6 & -6.4 \\
E stonia & 4.4 & -0.2 \\
H ungary & 52.9 & -5.7 \\
L atvia & 16.8 & -1.8 \\
Lithuania & 23.6 & -1.9 \\
Poland & 43.3 & -4.1 \\
Romania & 24.6 & -2.7 \\
Slovak Republic & 39.3 & -4.6 \\
Slovenia & 27.9 & -1.8 \\
\hline U nweighted average & 31.7 & -3.0 \\
\hline
\end{tabular}

Source: Tables 9 and 10 in E uropean Commission (2002d).
GDP growth, as they catch up with Western $E$ urope in terms of income per capita, and higher inflation due to the Balassa-Samuelson effect (according to which higher productivity growth in the tradables sector in catching-up countries than in already rich countries leads to higher wage growth and thus to higher price rises in the nontradable sector, as discussed in E E A G , 2002). ${ }^{12}$

We believe there is a case for revision of the fiscal rules in the $E U$ along the lines we have proposed. We have deliberately chosen the debt intervals in Table 2.8 such that our reform proposals would not accommodate the current budget problems of France, Germany, Portugal and I taly. The former three countries will all have debt-to-GDP ratios in 2003 of close to 60 percent and Italy has a ratio of close to 110 percent. It is true that the recent deterioration of the budget balances in these countries is associated with the workings of the automatic stabilisers, which dampen the present cyclical downswing. The root cause of the current budgetary problems is insufficient fiscal retrenchment in the preceding boom. R elaxing the rules such as to accommodate the current situation would, however, completely undermine the credibility of fiscal constraints at the EU level. It is not a good strategy to try to solve short-term problems by adjusting the long-term rules. The budget developments in some member states might imply that they are in the end fined if there is a drawn-out recession. This may not be all bad. Once a member state like Germany has been exposed to such fines, there would be little doubt that the sanction procedures are credible.

The current German situation may seem particularly awkward, as there are indications of a much larger negative output gap than in other euro countries (see Chapter 1). O ne possibility that should be considered is whether demand could be boosted through a "tax shift", that is through a reduction of

\footnotetext{
$12 \mathrm{D}$ ue to the initially low debt levels and the tendency to large debt-to-GDP reductions following from high nominal GDP growth, our proposed link between debt and deficit ceiling is also likely to give the accession countries more scope for investment in public infrastructure than the incumbent EU member states, which would seem desirable.
} 


\section{B ox 2.4}

\section{D ifferent measures of the government's financial situation}

The gross government debt concept used in the M aastricht Treaty is only one of several possible measures of the government's financial position. This box reviews various measures.

- G ross government debt nets out all claims and liabilities within the government sector, but claims on the private sector are not included.

- A nother debt concept is net government debt, which deducts government claims on the private sector from the gross debt.

- Conventional measures of government gross and net debt do not take account of pension obligations, but only refer to explicit debt. Pension obligations can be thought of as "implicit debt". Y et another measure is thus total explicit and implicit debt.

- If one adds in the real capital assets of the government, one obtains the net worth of the government.

Theoretically, net worth is the most relevant measure of the government's solvency (B uiter et al., 1993; B uiter, 2001; B alassone and Franco, 2000) R eal capital assets must then be assessed according to market values and not according to historic costs, as it is the ability to generate future revenues that is of interest. H owever, in practice there are huge problems of evaluation. Theoretically, net debt is also a more relevant concept for government solvency than gross debt, as a government can in principle draw on claims on the private sector. But here, too, there may be problems of evaluation (although smaller than for real capital assets). For example, many government loans to the private sectors may be "soft ones" with a large ingredient of subsidisation (this is likely to be a severe problem in the transition economies in E astern E urope) (B uiter et al., 1993; Föttinger, 2001).

It is not self-evident how implicit pension debt should be regarded, since pension obligations are less firm than ordinary debt obligations. On the one hand, pension obligations are a policy variable that is subject to possible change through reforms of pension systems. On the other hand, there is a political commitment to honour these obligations. Similarly, one could argue that there are very strong commitments also to some other government expenditures, such as health care and long-term care expenditures. By al so regarding the path of such expenditures as exogenous (for example, by assuming age-related spending increases, as discussed in Box 2.2), and by assuming unchanged policies with respect to taxes and other expenditure categories, one can forecast future budget balances. Computing the discounted present value of such tax and expenditure streams yields a "broader" measure of implicit debt, albeit one that can more easily be changed through policy action. A dding "implicit debt" calculated in this way to explicit debt is one way of assessing the need for fiscal adjustment in order to

employers' payroll taxes that is financed by increases in taxes that fall on employees, such as ensure fiscal sustainability. A Iternatively, fiscal sustainability indicators can be expressed as the immediate and permanent change in the budget balance necessary to meet various definitions of long-run fiscal sustainability (B lanchard et al., 1990; B alassone and Franco, 2000). It is a general rule that the more theoretically rel evant the measure of the government's financial situation is, the larger are the practical evaluation and measurement problems. So, there is a trade-off between theoretical relevance and practical applicability when choosing a measure as a basis for policy.

Table 2.10 presents four different measures of the government financial situation in 2001 for the $\mathrm{E} U$ countries. The first column shows government gross debt according to the E uropean Commission. The second column shows the same measure according to the OECD. Column 3 presents explicit government net debt according to the OE CD. Column 4 shows "total" (explicit + implicit) net debt according to Frederiksen (2002), where the implicit debt has been calculated as the discounted value of future net expenditures "associated with current expenditure and tax policies", thus taking into account inter alia pension obligations and expected increases in health-related expenditures. The numbers in parentheses rank the countries according to the various measures. Table 2.11, finally, shows the correlations between the different measures.

Several observations may be made from the tables. The Commission and OECD measures of gross debt are highly correlated, but not identical. The average government net debt ratio is $15-20$ percentage points lower than the gross ratios. There is a high correlation between the net and gross debt measures. The largest discrepancies refer to the N ordic countries (D enmark, Finland and Sweden), all of which have substantially lower net than gross debt.

"Total net government debt", including also implicit pension debt and the discounted present value of future age-related expenditure increases, is five to six times larger than explicit government net debt. There is a positive but weak correlation between explicit gross debt and "total net debt", whereas there is a weak negative correlation between explicit net debt and "total net debt". The weakness of the correlations is explained by a few countries, whose relative positions change dramatically when "implicit debt" is included. I taly, which has very low "implicit debt", then moves from being the most indebted country to being a low-debt country, whereas Finland and Ireland move from relatively low to relatively high levels of government "debt". A s can be seen from Table 2.11, the correlations increase substantially if these countries are removed from the comparison.

employee contributions to the social security system, income taxes or VA T. Such a tax reform rep- 
Table 2.10

D ifferent measures of government debt as percentages of G D P for the E U countries, 2001

\begin{tabular}{|c|c|c|c|c|}
\hline & $\begin{array}{l}\text { G ross govern- } \\
\text { ment debt } \\
\text { (EU Com- } \\
\text { mission) }\end{array}$ & $\begin{array}{l}\text { G ross govern- } \\
\text { ment debt } \\
(\mathrm{OECD})\end{array}$ & $\begin{array}{l}\text { Explicit net } \\
\text { government } \\
\text { debt }\end{array}$ & $\begin{array}{l}\text { "Total net } \\
\text { government } \\
\text { debt" }\end{array}$ \\
\hline $\begin{array}{l}\text { L uxembourg } \\
\text { I reland } \\
\text { U nited Kingdom } \\
\text { Finland } \\
\text { D enmark } \\
\text { N etherlands } \\
\text { Portugal } \\
\text { Sweden } \\
\text { France } \\
\text { Spain } \\
\text { G ermany } \\
\text { A ustria } \\
\text { G reece } \\
\text { B elgium } \\
\text { Italy }\end{array}$ & $\begin{array}{r}5.5(1) \\
36.6(2) \\
39.0(3) \\
43.6(4) \\
44.5(5) \\
53.2(6) \\
55.6(7) \\
56.0(8) \\
57.2(9) \\
57.2(9) \\
59.8(11) \\
61.7(12) \\
99.7(13) \\
107.5(14) \\
109.4(15)\end{array}$ & $\begin{array}{r}5.5(1) \\
36.5(2) \\
52.5(5) \\
43.6(3) \\
46.4(4) \\
53.2(7) \\
55.6(8) \\
52.9(6) \\
64.8(11) \\
69.1(12) \\
60.3(9) \\
61.7(10) \\
99.7(13) \\
108.2(14) \\
108.7(15)\end{array}$ & $\begin{array}{r}32.0(5) \\
30.9(4) \\
-47.9(1) \\
22.9(3) \\
42.1(7) \\
53.0(11) \\
1.0(2) \\
42.1(7) \\
39.8(6) \\
43.5(9) \\
47.0(10) \\
100.0(14) \\
98.9(13) \\
96.5(12)\end{array}$ & 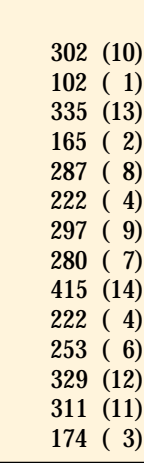 \\
\hline $\begin{array}{l}\text { G D P-weighted average } \\
\text { U nweighted average } \\
\text { Standard deviation } \\
\text { Coefficient of variation }\end{array}$ & $\begin{array}{r}63.0 \\
59.1 \\
26.9 \\
0.5\end{array}$ & $\begin{array}{r}69.1 \\
61.2 \\
26.5 \\
0.4\end{array}$ & $\begin{array}{r}48.8 \\
43.0 \\
37.9 \\
0.9\end{array}$ & $\begin{array}{r}233 \\
264 \\
78 \\
0.3\end{array}$ \\
\hline
\end{tabular}

Note: G ross government debt is total government debt, where only claims and liabilities within the government sector have been netted out. Explicit net government debt deducts government claims on the private sector from gross liabilities. "Total net government debt" includes also "implicit" government debt associated with future net revenue consequences of current expenditure and tax policies (thus reflecting also inter alia future unfunded pension obligations and projected incresases in other age-related government expenditures). The numbers in paranthesis give country rankings.

Source: Gross government debt: the EU Commission and the OECD. Explicit net government debt: the OE CD. "Total net government debt": Frederiksen (2002). reductions in the real labour cost and relative wage levels vis-à-vis other euro countries are at present prevented - or take a very long time to accomplish - because of downward money wage rigidity: it is very difficult to reduce money wage increases below those of the other euro countries at a low rate of inflation. The expenditure switch in favour of German products that a real exchange rate depreciation would achieve is motivated by a weaker demand situation in Germany than in the rest of the euro area and would most likely have occurred through an ordinary exchange rate depreciation in the absence of a common currency.

\subsection{D epoliticising E U surveillance and excessive deficit procedures}

The decision of the European Council in early 2002 not to follow the Commission's recomresents a fiscal policy to stimulate the economy without incurring a larger budget deficit. The policy is often labelled an "internal devaluation", as it reduces the real labour cost and depreciates the real exchange rate in a similar way as a reduction in the external value of the currency (Calmfors et al., 1997; Calmfors, 1998). Such internal devaluations were made in Denmark in the late 1980s and in Sweden in the early 1990s.

The underlying assumption behind the proposal of a German internal devaluation is that appropriate

mendation to give Portugal and Germany early warnings for their failure to meet their budget targets, after heavy lobbying on the part of these countries, have seriously undermined the credibility of the fiscal rules. Not least was the suspicion reinforced that it may be much more difficult to "shame" a large country than a small one. It goes without saying that the handling of the current deficits in Portugal, G ermany, France and I taly will be an "acid test" of the credibility of the EU fiscal framework.

A fundamental problem is the political character of EU decisions regarding the budget situation in individual countries. The finance ministers in the Ecofin Council have a strong incentive to act strategically as the budgetary surveillance process and the excessive deficit procedure have the character of a repeated game: by adopting a forgiving attitude towards colleagues with deficit problems, the risk of being branded oneself in similar situations in the future 
is reduced. If it is difficult to agree even on a relatively harmless early warning, it may be almost impossible to agree on harsher sanctions that involve both a financial cost and a loss of national prestige. Fines also risk triggering serious political conflicts among the member states, which goes directly against the aim that the $E U$ should foster integration and common understanding (U hlig, 2002).

The root of the problem is that $E U$ monitoring of the fiscal situation in individual member states is in the end done by the politicians responsible for these very situations. This is an unsatisfactory state of affairs. Our political systems usually draw a sharp dividing line between making the laws (which is done by elected politicians) and applying them (which is done by an independent judiciary). The budgetary surveillance process and the excessive deficit procedure clearly violate this principle.

The Commission has proposed that it alone should be given the power to issue early warnings in the budgetary surveillance process. The drawback of this proposal is that the Commission has weaker political legitimacy than the Council. Still, we endorse the proposal as a better alternative than the present arrangement. $B$ ut it is less clear that $a$ similar solution would be preferable for the excessive deficit procedure. Buti et al. (2002) have proposed that the Commission should be responsible for determining the existence of an excessive deficit and for giving a first warning to the member state in question. The next step would then be that the Council gives a second warning and requires corrective action to be taken. In the final step, the Council would take the decisions on sanctions, acting on a proposal from the Commission, which would have to be followed unless there is a unanimous decision not to do so.

A $n$ alternative way of depoliticising the excessive deficit procedure would be to transfer the decisions on sanctions from the political level of the Council to the judicial level of the E uropean Court of J ustice. The natural procedure would then be for the Commission to take violations of the excessive deficit criterion to the Court, which would then make the ultimate decisions on deposits and fines, possibly after hearing a standing panel of independent economists. Specific procedures would then have to be followed to ensure a speedy process, which is necessary in order to create the proper incentives for avoiding excessive deficit situations.
O ur two proposals of making the deficit rules more flexible and revising the decision process on excessive deficits may appear unrelated. In fact, they are not. The more credibly the fiscal rules are enforced, the greater the scope for changes that introduce more flexibility.

\section{Is there a case for delegation of national fiscal policy?}

Section 2 focused on possible reforms of the $E U$ fiscal rules. There is, however, a risk that too much of the fiscal policy discussion focuses on the EU. The foundations of good fiscal policy must be laid at the national level. I incentives for well-balanced policies are too weak there, political conflicts about the fiscal stance of individual member states will arise continuously at the EU level, which will undermine the legitimacy of the common rules The risk is all the greater, as there is some evidence that peer pressure at the $\mathrm{E} U$ level exerts less influence on large than on small member states (von $\mathrm{H}$ agen et al., 2002).

The fiscal policy framework at the E uropean level relies mainly on the common rules with numerical targets in the Maastricht Treaty and the SGP, whereas it has been left to the member states to decide on the national institutional frameworks to ensure compliance. A nother strategy would have been to focus on common standards for the design of national fiscal institutions and decision procedures. The main reasons why the latter method was not adopted is probably that it was considered to imply much greater interference with national sovereignty and to be associated with greater monitoring problems (B eetsma, 2001; B uti and Giudice, 2002). B ut the recent deficit experiences of some EU states have vividly illustrated the difficulties inherent in a system based mainly on the enforcement of common numerical targets. This raises the issue of whether one should not rely to a larger extent on common standards for national fiscal institutions. A parallel would be the common regulation of the legal status of the national central banks, which applies also to non-EMU members. The argument is that it might pay to take the oneoff cost of reforming national institutions according to commonly agreed principles, because this would reduce the risks of inappropriate fiscal policies in individual member countries and hence the risks of political conflicts at the $\mathrm{E} U$ level. 
Such common principles of national fiscal policy frameworks could take the form of each member state adopting a law on fiscal policy that must meet certain minimum standards (see also Swedish Government Commission on Stabilisation Policy in the E MU, 2002; and Calmfors, 2002). The law should specify long-run goals for the path of government debt and/or the medium-term (cyclically adjusted) fiscal balance. These goals must be consistent with (but could be more ambitious than) the requirements of the M aastricht Treaty and the SG P. Such a law should also define clearly the short-run stabilisation objectives of fiscal policy. It should be clarified to what extent one intends to rely on the automatic stabilisers and in what circumstances discretionary policy action will be undertaken. Similar to the A ustralian Charter of Budget H onesty, the government could be obliged to indicate which tax and expenditure changes are temporary (because they are undertaken for stabilisation purposes) and "the process for their reversal" (Business Council of A ustralia, 1999). To shorten decision lags and reduce the risk that income distribution aspects dominate stabilisation considerations in concrete situations, a law on fiscal policy could also select in advance a small number of fiscal policy instruments to choose from if the need for discretionary measures were to arise (Swedish Government Commission on Stabilisation Policy in the EMU, 2002; Calmfors, 2002). In addition, a law on fiscal policy ought to regulate the budget policies of sub-national local governments such as to ensure compatibility with the overall national fiscal objectives.

O ne should also try to ensure that the stabilisation programmes submitted to the $\mathrm{E}$ cofin Council by the member states do not live a life of their own in the national decision process, but are approved by the parliament as part of the normal budget process, as has been suggested by von $\mathrm{H}$ agen et al. (2002). Such an integration of the fiscal processes at the E uropean and national levels would seem necessary to ensure consistency between national budget objectives and commitments at the E uropean level.

\subsection{L essons from the decision-making process for monetary policy}

Section 1 discussed why monetary policy is today generally regarded as a much more effective stabilisation policy tool than fiscal policy. This is not because fiscal policy is intrinsically less effective in a technical sense, but because the decision-making process involves much greater risks of bad timing and expansionary bias. Whereas monetary policy has been delegated to independent central banks, which have been given clear stabilisation objectives, fiscal policy is decided in drawn-out parliamentary processes where stabilisation aspects become intertwined with income distribution and social efficiency aspects. This raises the question of whether one can learn some lessons for the fiscal policy decision-making process from the institutional changes that have been adopted in the field of monetary policy. Indeed, there exists recent literature which asks precisely this question. The contributions include von $\mathrm{H}$ agen and $\mathrm{H}$ arden (1994), E ichengreen, von $\mathrm{H}$ agen and $\mathrm{H}$ arden (1995), SaintPaul (1995), Calmfors (1995), W ren-L ewis (1996, 2000, 2002), Blinder (1997), B all (1997), Business Council of A ustralia (1999), the E conomist (1999), Eichengreen, Hausmann, and von Hagen (1999), Seidman (2001), Wyplosz (2002), and the Swedish G overnment Commission on Stabilisation Policy in the EMU (2002).

The main theme in this literature is whether one could improve both budget discipline and the effectiveness of fiscal policy as a stabilisation tool through delegation of some fiscal policy decisions to an independent agency that is assigned clear policy objectives by the political system, and whether this would be compatible with accepted principles of democratic governance. The fiscal agency would then be allowed to decide fiscal policy within predetermined limits without political interference in a way similar to how independent central banks pursue monetary policy. D ifferent authors have used different terminologies for such a fiscal policy agency. We shall refer to it as a fiscal policy committee (FPC for short) to stress the parallel with monetary policy committees in central banks.

The proposals vary as to the range of decisionmaking powers given to the FPC. The most farreaching proposal is that of Blinder (1997) who proposes that an FPC should be given the power to decide the tax structure but not the level and composition of government expenditures, on the basis of general objectives for income distribution and social efficiency formulated by the legislature. $B$ linder supports the delegation with the argument that appropriate decisions on tax policy require a long-term perspective, technical expertise, and that undue influences from particularistic interest groups are avoided. 
O ther far-reaching proposals are those of von $\mathrm{H}$ agen and $\mathrm{H}$ arden (1994), Eichengreen, von $\mathrm{H}$ agen and $H$ arden (1995), and Eichengreen, Hausmann and von $\mathrm{H}$ agen (1999). These contributions propose that a FPC should decide a "debt change limit", which the government would be obliged to follow. Here, the motivation is to enhance fiscal discipline by taking the decisions on long-run debt accumulation out of the political sphere which is assumed to suffer from a deficit bias.

However, most of the proposals focus strictly on the stabilisation aspect. This means that not only decisions on the size and structure of government expenditures, but also on the basic tax structure and long-run debt accumulation (the fiscal balance over the cycle or the cyclically adjusted annual fiscal balance) should remain in the political sphere. ${ }^{13}$ The FPC would only be delegated the power to decide how the budget balance should vary around the medium-term target depending on the cyclical situation or to vary certain tax rates around predetermined base levels. The underlying idea is that stabilisation of the business cycle is a commonly shared objective, which requires more technical expertise but fewer political trade-offs than other fiscal policy decisions. A nother motive is to separate the stabilisation policy aspects of fiscal policy from income distribution and resource allocation aspects such that stabilisation decisions are not "contaminated" by other considerations. The idea is also to reduce the risk that fiscal policy changes undertaken for stabilisation reasons involve a deficit bias. 0 ther motives are to shorten decision lags and to make it easier to reverse fiscal policy decisions.

\subsection{Two models of delegation}

The idea that part of fiscal policy could be delegated is no doubt unfamiliar and surprising to most people. To quote the E conomist (1999), most people would probably regard "with horror" the idea that tax rates would be adjusted "by a band of unelected officials". A the same time, there has been a general trend in many areas of economic policy making for politicians to focus more on setting the overall objectives and then delegate the

${ }^{13} \mathrm{~N}$ ote that targets for the "fiscal balance over the cycle" and "the cyclically adjusted annual fiscal balance" are not identical requirements. A target for the fiscal balance over the cycle implies, for example, that past misjudgements of the cyclically adjusted fiscal balance should be compensated for in later phases of the cycle, whereas this is not the case with the second formulation. operational decision-making to various bodies. The idea is to remove the actual implementation of policy from day-to-day politics. A reas where this has happened include, in addition to monetary policy, competition policy (M ajone, 1996) as well as regulation and supervision of financial markets (see Chapter 4).

Even though delegation of national fiscal policy decisions to independent national bodies is not at present on the political agenda, there is a case for initiating a discussion of this possibility. It can be viewed as a contrast to the recent proposals that the European Commission should play a larger role in evaluating and approving national fiscal policies, which also represents a delegation to a non-elected body. If one takes the subsidiarity principle (see Chapter 3) seriously, one should explore solutions at the national level as an alternative to an enhanced role for the European Commission in the area of fiscal policy.

In the literature on fiscal policy delegation, two basic models have been proposed. The first model implies that the FPC decides the annual budget balance, the second one that the FPC is allowed to vary specific tax rates or government expenditures.

The FPC decides the annual budget balance

A ccording to this model, which has been proposed by Wyplosz (2002a,b), the parliament would decide a budget target over the cycle or a target for the cyclically adjusted budget balance. Given this constraint and some general guidelines on the roles of automatic stabilisers and discretionary policy (for example, specifying that discretionary fiscal policy measures should only be undertaken when output gaps are of a certain size, as proposed by the Swedish G overnment Commission on Stabilisation Policy in the EMU, 2002), the FPC would be given the right to decide the annual budget target. The parliament would commit itself to follow the recommendations of the FPC. The FPC would also have to monitor both budget and cyclical developments over the fiscal year and have the power of requesting amendments to the budget.

A ccording to this model, the parliament retains the right to decide through which tax and expenditure changes the annual budget target should be met. This means that the parliament controls the income distribution and social efficiency aspects of fiscal policy. 
As the FPC would determine only the variations around the path of government debt over the cycle, but not the path itself, its decisions would have a negligible effect on intergenerational equity. The flip side of retained political decisions on all individual taxes and expenditures is that the FPC does not acquire full control over the stabilisation aspects of fiscal policy. To the extent that different taxes and expenditures have different multipliers, as discussed in Section 1.2, political decisions on tax and expenditure changes consistent with the budget target of the FPC can still affect aggregate demand to a significant degree. This may seriously complicate the task of the FPC, as it may not be possible to offset such effects without violating the long-run target for the fiscal balance.

The FPC varies individual tax rates or government expenditures

A ccording to the second model (see for example B all, 1997; B usiness C ouncil of A ustralia, 1999; and Seidman, 2001), the parliament would again take the decision on the medium-term target for the fiscal balance. But in contrast to the first model, the political sphere would only decide base rates for some taxes and base levels for some government expenditures (which would have to be consistent with the medium-term target for the fiscal balance). The FPC would then be granted the right to vary these tax rates and expenditure levels around their base values within prespecified limits in order to stabilise cyclical fluctuations. This could be done in two different ways.

A first possibility is that the parliament determines in advance which fiscal instruments should be varied if the need arises. The simplest alternative is to give the FPC control over only one specific fiscal instrument. A Iternatively, the parliament could prescribe ex ante that discretionary fiscal policy action should have a given composition (for example, 30 percent of a fiscal stimulus should be a VAT decrease, 20 percent a reduction in employers' payroll taxes, 10 percent a reduction in personal income taxes for low-income earners, and 40 percent an increase in government consumption), as proposed by Seidman (2001). This way the FPC decides only the overall size of fiscal stabilisation measures, but the political sphere retains control also over the short-run income distribution effects.

A disadvantage of predetermining the composition of fiscal stabilisation measures is that different pol- icy responses may be called for depending on the type of macroeconomic disturbance. For example, an increase in government employment may not be an appropriate response to a reduction in export demand. So, deciding on the composition of stabilisation packages once and for all may unduly constrain policy choices in a given situation.

Predetermining the composition of discretionary stabilisation measures would also require the parliament to form an informed view of which instruments are "on average" the best. This choice would be most important if one only delegates a single fiscal instrument to the FPC. Which one should then be chosen? There seems to be a presumption in the delegation literature in favour of taxes (B all, 1997; B linder; 1997; B usiness C ouncil of A ustralia, 1999). If so, one might argue that VAT changes could be a good candidate, as they affect private consumption in a similar way as interest rate changes, which are already subject to delegation (see Section 1.2). Delegation of the decision on VAT changes would shorten decision lags. This is likely to be particularly important for this instrument, because long decision lags could actually reverse the effect of policies: for example, a temporary VAT increase to cool off a boom will have an expansive demand effect in the period before it enters into force (see Section 1.2). H owever, variations in government consumption, for example through variations in general grants to regional and municipal authorities, might very well also be a suitable stabilisation policy parameter for an F PC. A s discussed in Section 1, recent research suggests that expenditure multipliers may be larger than tax multipliers. Delegation to an FPC could mitigate the problem of irreversibility, which is usually regarded an important argument against increases in government expenditures in recessions (Wijkander and Roeger, 2002; Swedish Government Commission on Stabilisation Policy in the EMU, 2002) ${ }^{14}$

A nother possibility would be that the parliament decides on a set of fiscal instruments that the FPC can vary within certain limits, but leaves the committee complete freedom to choose which of these instruments to be used in a specific situation. This

${ }^{14}$ A nother proposal is that of Saint-Paul (1995), who proposed that the size and composition of active labour market programmes should be delegated to an independent labour market board. This idea has been analysed theoretically by Calmfors (1995) and Johansson (2002) 
would allow the FPC to use the instrument combination it finds most appropriate at each point of time. It would also allow the FPC to adjust the use of instruments to changes over time in the way economists judge their effectiveness. ${ }^{15}$ With such discretionary power over which instruments to use in specific situations, the FPC acquires a larger but still limited - influence on income distribution (and social efficiency), as there is no longer a requirement that individual tax rates and government expenditures be changed symmetrically over the cycle.

There is one important difference between letting the FPC vary the deficit target and letting it vary specific tax rates or expenditures. A ccording to the former arrangement, the estimates of the FPC of the cyclical situation of the economy are automatically binding for the government. With the latter arrangement, one might fear that overoptimistic judgements of potential output on the part of the government causes it to systematically overestimate the cyclically adjusted balance, which might contribute to a deficit bias. A possible way of addressing this problem is to require that the estimates of the cyclically adjusted balance be based on the judgements of the FPC in the latter arrangement, too.

\subsection{Is there a democratic problem with delegation?}

To ensure that fiscal stabilisation policy decisions are taken at arm's length from day-to-day politics, it has been suggested that the fiscal policy committee should have a similar degree of independence as a central bank. This would imply that the committee is not permitted to take instructions regarding individual decisions from the government or the parliament, and that the latter institutions are not permitted to give such instructions. A ppointments should be long-term and non-renewable. Committee members should have professional competence: either earlier practical experience of economic policy making or analysis from ministries of finance, central banks, international organisations (like the IMF, the World Bank or the E uropean Commission), private banks and so on, or academic competence in the field of stabilisation policy and macroeconomic analysis. The FPC should be granted a long-term budget, which could not be changed from year to year.

\footnotetext{
15 In view of the way "fashions" change over time among econo-
} mists, this might not, however, be an unmixed blessing.
The most common objection to delegation of fiscal stabilisation decisions is that it would interfere with conventional principles of democratic decision-making. How should one think about this?

In any democratic society there exists the general problem of how to allocate decisions between the political and the technocratic spheres. This is done in different ways in different societies and the allocations also change over time. $D$ ifferent trade-offs are made in different areas of policy-making. There are no given standards, although there is a tendency to regard the current government institutions "as if they were the natural order of things" (Blinder, 1997) and not subject to the possibility of reforms until the very moment when such reforms take place.

The most important consideration for where to draw the line between political and technocratic decisions in a given area is the relative importance of value judgements and technical expertise (M ajone, 1996). The reason why most proposals on the delegation of fiscal policy exclude the size and composition of government expenditures, the tax structure and the size of long-run government debt is that value judgements on income distribution are crucial for these decisions. In contrast, macroeconomic stabilisation involves much less of value judgements and is more a question of technically finding the best ways of achieving commonly shared objectives (see Section 3.1). Indeed, it is difficult to find any fundamental difference in this respect between fiscal policy and monetary policy to stabilise the business cycle. A s noted by Blinder (1997), most of the arguments against delegation of fiscal stabilisation policy decisions could also be used against the already existing delegation of monetary policy.

To ensure the legitimacy of delegation of fiscal policy, an FPC would, of course, have to be subject to democratic oversight and accountability. Even if delegation is likely to improve fiscal policy "on average", democratic control would be needed to reduce the risk that the $\mathrm{FPC}$ might at times pursue idiosyncratic objectives or just make bad technical judgements. Some lessons could be learnt from monetary policy, but one could also go further in some respects.

A ppointments of the members of the FPC would be made by the government and be sub- 
ject to approval by the parliament. The candidates should be subject to questioning in parliament before they are confirmed, as is the case, for example, with members of the Federal Reserve Board in the $U$ nited States (in the Senate). There is a similar procedure for the members of the $E$ xecutive $B$ oard of the $E C B$ in the European Parliament, although the parliament's confirmation is not formally required.

- The objectives of the FPC should be determined by the legislature. A high degree of transparency should be required of the committee. It would have to explain all its decisions to the general public and to publish background fiscal reports (corresponding to the inflation reports of, for example, the Bank of England and Sveriges Riksbank) at regular intervals. The minutes of the FPC meetings and voting records should be published. The members of the FPC should regularly take part in public hearings in the parliament.

- The parliament should carry out ex post evaluations of the committee's performance with the help of outside expertise. If the FPC fails over a period of years to achieve its objectives by a large margin - which needs to be given a clear operational definition ex ante - the parliament should have the possibility of dismissing the whole committee or individual members of it. Preferably, such dismissal should require a qualified majority to protect the FPC against misuse of this possibility.

- One could also conceive of an escape clause, which would enable the parliament to override an individual decision by the FPC. A gain, this could require a qualified majority.

- The ultimate check on a system of delegation is, of course, the possibility to abolish the system altogether if it does not work in the desired way.

In any discussion of democratic control, it is important to distinguish between the formal aspects of accountability and how the process works in practice. It has been argued that in practice there may be more accountability with the delegation of a specific "technical" task to an independent committee, with clearly defined objectives against which to measure performance, than to have it executed as one of many simultaneous tasks by the government (M ajone, 1996). The argument is that the assignment of well-defined tasks to independent bodies makes it easier to "nail down" mistakes than if a government is at the same time to be held accountable for its performance in a large number of fields through the ordinary political process.

\subsection{Weaker forms of fiscal policy committees}

It is an open question whether one could find forms for delegating the decisions on fiscal policy aiming at macroeconomic stabilisation that would be acceptable to the general public. However, there is good reason to initiate a discussion. M ost people are likely to consider weaker forms of delegation politically more realistic, at least in a short-term perspective.

O ne such possibility would be to give an FPC control only over a well-defined "rainy-day" stabilisation fund, but leave the political sphere in full command of the rest of fiscal policy (see also Section 2.3). Such a fund could be built up to a maximum level through specific tax receipts in booms and then run down through tax rebates in recessions. $M$ any might regard this alternative as "Iess controversial" than the proposals in Section 3.2, because the powers of the FPC would be more clearly delineated and would not interfere with the normal budget process. The idea has some resemblance with the buffer funds in Finland that were described in Section 1.2. These funds differ, however, from the institutions discussed here, because they are of a corporatist nature: they are controlled by the central labour market organisations and not by an independent committee of experts. ${ }^{16} \mathrm{~A}$ general drawback of the stabilisation fund solution, as outlined here, is that it might introduce a "double command" to the extent that the government uses the fiscal parameters under its control to influence the cyclical situation.

A nother alternative has been suggested by $B$ linder (1997). A ccording to this, the ultimate decision on a fiscal policy proposal of the FPC should be taken by the legislature, but be subject to a simple up-ordown vote. The proposal would thus have to be either accepted without any changes or rejected. In the latter case, one possibility could be to freeze tax rates and nominal government expenditures at last year's level. Such an arrangement would give the political sphere more influence than with delegation of the actual decision-making, but the FPC would still have a strong hand, as automatic "fiscal

16 Formally, the use of the Finnish buffer funds also requires the formal consent of the government (the minister of social affairs). 
drag" would tend to strengthen the budget balance in case the committee's proposal is rejected by the parliament.

Finally, one could give the FPC only advisory functions, but with some teeth as proposed by the Swedish Government Commission on Stabilisation Policy in the EMU (2002). ${ }^{17}$ This alternative is our preferred option for the near future. The FPC could then be assigned the task of independently estimating the cyclical situation of the economy (the output gap) and various tax and expenditure elasticities on which the government must base its budget calculations. The FPC could also be required to make public recommendations to the government on the annual budget targets and on specific tax and expenditure changes. The government could be more or less free to deviate from the recommendations of the FPC. This might be allowed only under exceptional circumstances. A Iternatively, the government might be free always to deviate from the recommendations, but would then be required to formally explain the reasons in a specific parliamentary session. Calmfors (2002) has proposed that the minister of finance then should be obliged to take part in a "reversed" public hearing, where he/she has to explain to the FPC why its recommendations are not being followed. The idea of these proposals is to increase the governments' reputational costs of deviating from the judgements of the FPC.

The weakest form of an independent fiscal policy committee is just to let it take part as another voice in the public debate on the economy. This is more or less the way in which the Sachverständigenrat in Germany and the E conomic Council in Denmark work. In that case the influence of the independent group of experts depends mainly on the reputation it can build up over time through its judgements and its ability to market itself. Its role can be enhanced by requiring the government to respond formally to the reports of the expert group (Swedish Government Commission on Stabilisation Policy in the EMU, 2002).

Some contributions have proposed that monetary policy committees (or executive boards) in existing

\footnotetext{
17 See also W ren-L ewis (1996) and Wyplosz (2002a) for similar proposals.

$18 \mathrm{H}$ owever, a system where actual fiscal policy decisions are taken by an FPC in the form of a national central bank and where the decisions could be overridden by parliamentary decisions or the FPC be dismissed would not be desirable. It would not be consistent with the independence of the E uropean Central B ank System, which now forms a corner stone of the monetary union.
}

central banks could function also as fiscal policy committees (B all, 1997; Seidman, 2001; and W renL ewis 2002). O ne motive is that there would be small set-up costs if one uses an existing institution which already has an independent status and has acquired credibility for prudent stabilisation policies. A Iso, it might be regarded as less controversial to build on an already accepted institution rather than to establish a new one. A nother argument has been that such an arrangement would facilitate coordination between fiscal and monetary policy. However, this argument does not apply to EMU, where monetary policy is centralised and fiscal policy decentralised. Here, it would rather be a question of finding a new role for the boards of the national central banks. ${ }^{18}$

$\mathrm{N}$ ational fiscal institutions that enhance the incentives for fiscal discipline and effective stabilisation policies reduce the risk of conflicts between national stabilisation objectives and the common $\mathrm{EU}$ fiscal rules. In a longer time perspective, the common fiscal framework in the EU might allow for and even encourage delegation of national fiscal stabilisation decisions along the lines we have suggested. O ne can conceive of several ways of doing this. For example, one could link our proposal of more flexible deficit ceilings in Section 2.2 to the existence of independent national fiscal authorities: low-debt countries could be allowed to use their higher deficit ceilings only if this is approved by the national FPC. Or if one adopts a system of extra-budgetary "rainy-day" funds, these might be used to avoid breaches of the three-percent deficit limit only after a decision by an independent national fiscal authority. Recommendations and early warnings in the case of deviations from set budget targets could also take into account how these relate to the decisions of an independent fiscal authority.

\section{R eferences}

A lesina, A. and R. Perotti (1995) "Fiscal Expansions and A djustments in OE CD Countries," E conomic Policy 21, 205-248.

Balassone, F. and D. M onacelli (2000) “E M U Fiscal R ules: Is There a Gap?," Working Paper no. 375, R ome: B anca d'I talia.

Balassone, F. and D. Franco (2001) "EMU Fiscal Rules: a New A nswer to an Old Question?," in: Fiscal Rules, Rome: Banca d'I talia, 33-58.

B alassone, F. and D. Franco (2000) "A ssessing Fiscal Sustainability: a R eview of M ethods with a View to E MU," in: Fiscal Sustainability, R ome: B anca d'I talia, 21-60.

B all, L. (1997) "A Proposal for the Next M acroeconomic R eform," Victoria E conomic Commentaries, M arch, 1-7. 
Bean, C. (1998) “D iscussion,” E conomic Policy 26, 104-107.

Beetsma, R. (2001) "D oes EMU Need a Stability Pact?'," in: A B runila, M. Buti, and D. Franco (eds), The Stability and G rowth Pact, $B$ asingstoke: Palgrave, 23-52.

Blanchard, O. (1990) "Suggestions for a New Set of Fiscal Indicators," Organization for Economic Cooperation and D evelopment Working Paper no. 79

Blanchard, O. (2001) "Country A djustments within Euroland L essons after Two Y ears," Working Paper, M IT

B lanchard, O. and R. Perotti (1999) "A n E mpirical Characterization of the $D$ ynamic $E$ ffects of Changes in G overnment Spending and Taxes on O utput," NBER Working Paper no. 7269.

Blanchard, O. and F. G iavazzi (2002) R eforms that Can Be Done: Improving the SGP through a Proper Accounting of Public Investment, mimeo, MIT and Bocconi U niversity.

Blinder, A . S. (1997) “Is G overnment Too Political?," Foreign A ffairs 76 (6), 115-126.

Blinder, A . S. (2001) "The E conomic Stimulus We N eed," N ew York Times, 28 September.

Bordo, M. D. and O. Jeanne (2002) "B oom-Busts in A sset Prices Economic Instability and Monetary Policy," CEPR Discussion Paper no. 3398

B runila, A ., M. B uti, and D. Franco (eds) (2001) The Stability and G rowth Pact, B asingstoke: Palgrave.

B uiter, W.H. (2001) "N otes on 'A Code for Fiscal Stability'," O xford E conomic Papers 53, 1-19.

B uiter, W.H ., G. Corsetti, and N. R oubini (1993) "E xcessive D eficits: Sense and Nonsense in the Treaty of M aastricht," E conomic Policy 8, 57-100.

Business Council of Australia (1999) "A voiding Boom/Bust: Macroeconomic Reform for a Globalised Economy," Discussion Paper no. 2, M elbourne: Business Council of A ustralia.

B uti, M ., S. Eijffinger, and D Franco (2002) R evisiting the Stability and $G$ rowth Pact: Grand D esign or Internal A djustment?, mineo, European Commission.

B uti, M ., D. Franco, and H. O ngena (1997) “Budgetary Policies during Recessions - Retrospective A pplication of the "Stability and Growth Pact' to the Post-War Period," E conomic Papers no. 121 European Commission.

B uti, M . and G. G iudice (2002) “M aastricht's Fiscal R ules at Ten:A n A ssesment," Working Paper, E uropean Commission.

Buti, M. and B. Martinot (2000) "Open Issues on the Implementation of the Stability and Growth Pact," National Institute E conomic R eview 174, 92-104.

B uti, M . and A . Sapir (eds) (1998) E conomic Policy in E M U :A Study by the E uropean Commission Services, Oxford: Oxford U niversity Press.

Calmfors, L. (1995) "What Can We Expect from A ctive Labour $M$ arket Policy," B eihefte der Konjunkturpolitik 43, 11-30.

Calmfors, L. (1998) "Macroeconomic Policy, Wage Setting and Employment - What Difference D oes the EMU Make?," Oxford Review of E conomic Policy 14, 125-151.

Calmfors, L. (2001) "M acroeconomic Policy Coordination in the E U : H ow Far Should It Go?," Swedish E conomic Policy Review 8 3-14.

Calmfors, L. (2002) "Fiscal Policy as a Stabilisation Policy Tool in the EMU," paper to the EPRU Network Conference, 23 May, Copenhagen U niversity.

Calmfors, L., A. Booth, M. Burda, D. Checchi, R. Naylor, and J.Visser (2001) "The Future of Collective Bargaining in E urope," in: T. B oeri, A. B rugiavini, and L. Calmfors (eds) The Role of Unions in the Twenty-First Century, Oxford: Oxford U niversity Press, 1-155.

Calmfors, L. and G. Corsetti (2002a) "A Better Plan to Loosen the Pact," Financial Times, 26 N ovember.

Calmfors, L. and G. Corsetti (2002b) “How to Reform Europe's Fiscal Policy Framework," forthcoming in World Economics Journal.
Calmfors, L., H. Flam, N. Gottfries, M. Jerneck, R. Lindahl, J. $\mathrm{H}$ aaland Matlary, C. Nordh Berntsson, E. Rabinowicz, and A. V redin (1997) E MU - A Swedish Perspective, Dordrecht: Kluwer A cademic Publishers.

Calmfors, L. and R. Nymoen (1990) "R eal Wage A djustment and E mployment Policies in the Nordic Countries," E conomic Policy 5 397-448.

Calmfors, L. and E. U ddén Sonnegård (2001) "Explaining Wage D evelopments," E conomic Review 4, 38-67.

Canzoneri, M .B. and B.T. D iba (2001) "The SG P: D elicate B alance or A lbatross?," in: A. B runila, M. Buti, and D. Franco (eds) The Stability and G rowth Pact, B asingstoke: Palgrave, 53-74.

D e G rauwe, P. (2002) “E urope's Instability Pact," Financial Times, 22 July.

The E conomist (1999) “E conomics Focus: Fiscal Flexibility: Could Finance M inisters L earn a Few Tricks from Central B ankers?"

The E conomist (2002) “The E uro-Z one's Stability Pact: R ules A re $M$ ade to Be Bent, A ren't They?," 27 July, 27-28.

E delberg, W., M . E ichenbaum, and J. Fischer (1998) U nderstanding the Effects of a Shock to Government Purchases, mimeo, Northwestern U niversity.

EEAG (2002) Report on the European E conomy, European E conomic A dvisory G roup at CE Sifo, M unich.

Eichengreen, B., J. von $\mathrm{H}$ agen, and I. $\mathrm{H}$ arden (1995) “ $\mathrm{H}$ urdles too $\mathrm{H}$ igh: Improving Budget Procedures Is the Best Preparation for EMU," Financial Times, 28 N ovember, 16

Eichengreen, B., J. von $\mathrm{H}$ agen, and R. Hausman (1999) "R eforming Budgetary Institutions in L atin A merica: The Case for a National Fiscal Council," Open E conomies Review 10, 415-442.

E ichengreen, B. and C. Wyplosz (1998) "The Stability Pact: M ore than a M inor Nuisance?," in: D.K.H. B egg, J. von H agen, C. Wyplosz, and K.F. Zimmerman (eds) E MU: Prospects and Challenges for the Euro, Oxford: Blackwell, 65-114.

Elmendorf, D.W. and N.G. M ankiw (1999) "Government D ebt," in: J.B. Taylor and M. Woodford (eds) Handbook of M acroeconomics vol. 1 C , A msterdam: E Isevier, 1615-1669.

European Commission (2001) "Public Finances in the EMU 2001," E uropean E conomy 3.

European Commission (2002a) "Public Finances in the EMU 2002," E uropean E conomy 3.

E uropean Commission (2002b) Communication from the Commission to the Council and the E uropean Parliament: Strenghening the Co-ordination of B udgetary Policies, B russels, $27 \mathrm{~N}$ ovember.

European Commission (2002c) "A utumn 2002 Economic Forecasts," European E conomy 5.

European Commission (2002d), "The EU Economy Review," E uropean E conomy 6 .

Fatás, A. and I. Mihov (2000) "The E ffects of Fiscal Policy on Consumption and Employment: Theory and Evidence," Working Paper, INSEA D.

Fatás, A . and I. M ihov (2001) "Government Size and A utomatic Stabilizers: International and Intranational Evidence," J ournal of International E conomics 55, 3-28.

Fatás, A . and I. M ihov (2002) "The Case for R estricting Fiscal Policy Discretion," Working Paper, I N SE A D.

Financial Times (2002a) "Fear of more EU Deficit Breaches," 27-28 July.

Financial Times (2002b) "Second A gain," 29 July.

Financial Times (2002c) "Commission Chief Hints that Pact Is on L ast L egs," 180 ctober.

Frederiksen, N.K. (2002) "Fiscal Sustainability in the OECD. December 2001," Working Paper, Ministry of Finance in D enmark.

Föttinger, W. (2001) “B alanced B udget Versus G olden R ule: O n the R emediability of Fiscal R estrictions," in: Fiscal Rules, R ome: B anca d'I talia, 331-366. 
Galí, J. (1994) "Government Size and M acroeconomic Stability," E uropean E conomic Review 38, 748-756.

G iavazzi, F. and M. Pagano (1996) "N on-K eynesian E ffects of Fiscal Policy Changes: International Evidence and the Swedish Experience," Swedish E conomic Policy Review 3, 67-103.

Giavazzi, F., T. Japelli, and M. Pagano (2000) "Searching for NonLinear Effects of Fiscal Policy: Evidence from Industrial and D eveloping Countries," E uropean E conomic R eview 44, 1259-1289.

von $\mathrm{H}$ agen, J. and I.J. Harden (1994) "National Budget Processes and Fiscal Performance," European Economy Reports and Studies 3, 311-408

von Hagen, J., A. Hughes, and R. Strauch (2002) "Budgetary Institutions for Sustainable Public Finances," in: M. Buti, J. von $H$ agen, and C. M artinez-M ongay (eds) The Behaviour of Fiscal A uthorities, B asingstoke: Palgrave, 94-112.

von $\mathrm{H}$ agen, J. and S. M undschenk (2001) "The Political E conomy of Policy Coordination in the E M U," Swedish E conomic Policy Review 8, 107-137.

von H agen, J., R . Perotti, and R . H ausmann (1998) Sustainability of Public Finances, London: CE PR

Hemming, R and M . K ell (2000) "Promoting Fiscal Responsibility: Transparency, R ules and Independent Fiscal A uthorities," in: Fiscal Rules, R ome: B anca d'I talia, 433-459.

Holm, P., J. Kiander, and P. Tossavainen (1999) "Social Security Funds, Payroll Tax A djustment and Real Exchange Rate: The Finnish Model," VATT, Government Institute for Economic R esearch, D iscussion Paper no. 198, H elsinki.

Johansson, A. (2002) "The Interaction Between Labor Market Policy and M onetary Policy: A $n$ A nalysis of Time Inconsistency Problems," in: E ssays on M acroeconomic Fluctuations and N ominal Wage Rigidity, Stockholm: Institute for International Economic Studies, 15-55.

Kell, M. (2001) "A n A ssessment of Fiscal Rules in the United Kingdom," I M F Working Paper W P/01/91.

Knight, B. and A . Levinson (1999) "R ainy D ay Funds and State Government Savings," N ational Tax J ournal, LII 3, 459-472.

Kopits, G. and S. Symansky (1998) "Fiscal Policy Rules," IMF Occasional Paper no. 162.

Leibfritz, W., D. Roseveare, and P. van den Noord (1994) "Fiscal Policy, Government Debt and Economic Performance", OECD E conomics D epartment Working Paper no. 144.

M ajone, G. (1996) Regulating E urope, London: R outledge.

McGranahan, L. (1999) State Budgets and the Business Cycle: I mplications for the Federal $B$ alanced $B$ udget $A$ mendment $D$ ebate, mimeo, Federal R eserve B ank of Chicago.

M elitz, J. (2000) "Some Cross-Country E vidence about Fiscal Policy Behaviour and Consequences for EMU," European Economy 2, 3-21.

van den N oord, P (2002) "A utomatic Stabilizers in the 1990s and beyond," in: $\mathrm{M}$. B uti, J. von $\mathrm{H}$ agen, and C. M artinez-M ongay (eds) The Behaviour of Fiscal A uthorities, Basingstoke: Palgrave, 130-148.

Nymoen, R . and A . Rødseth (1999) "Nordic Wage Formation and U nemployment Seven Years Later," Memorandum no. 10/99, Department of $\mathrm{E}$ conomics, $\mathrm{O}$ slo U niversity.

Pisani-Ferry, J. (2002) “Fiscal D iscipline and Policy Coordination in the Eurozone: A ssesment and Proposals," Working Paper, U niversité Paris-D auphine.

R amey, V. and M. Shapiro (1997) "Costly Capital Reallocation and the Effects of Government Spending," Carnegie-R ochester Conference Series on Public Policy 48, 145-194.

R otemberg, J. and M. Woodford (1992) "Oligopolistic Pricing and the $E$ ffects of A ggregate D emand on E conomic A ctivity," J ournal of Political E conomy 110, 1153-1207.

Seidman, L. (2001) “R eviving Fiscal Policy," Challenge 44 (3) , 17-42.

Storesletten, K ., C.I . Telmer, and A .Y Yaron (2001) “The Welfare Cost of B usiness Cycles R evisited: Finite Lives and Cyclical Variation in I diosyncratic R isk," E uropean E conomic R eview 45, 1311-1339.
Swedish Government Commission on Stabilisation Policy in the EMU (2002) Stabilisation Policy in the Monetary Union, SOU 2002:16, Stockholm: Fritzes.

Taylor, J.B. (2000) "R eassessing D iscretionary Fiscal Policy," J ourna of $E$ conomic Perspectives 14, 21-36.

U hlig, H . (2002) "O ne M oney, but M any Fiscal Policies in E urope: What A re the Consequences?," CE PR D iscussion Paper no. 3296.

Walton, D. (2002) “Europe's Stability Pact: In Need of New Clothes," G lobal E conomics Paper no. 81, G oldman Sachs.

Wijkander, H. and W. Roeger (2002) "Fiscal Policy in EMU: The Stabilization A spect," in. M. Buti, J. von Hagen, and C. M artinez M ongay (eds) The Behaviour of Fiscal Authorities, Basingstoke: Palgrave, 149-166.

W ren-L ewis, S (1996) "A voiding Fiscal Fudge," N ew E conomy 3, 128-132.

W ren-Lewis, S. (2000) "The Limits to Discretionary Fiscal Stabilization Policy," Oxford Review of Economic Policy 16 (4) 92-105.

W ren-L ewis, S. (2002) "Fiscal Policy, Inflation and Stabilisation in E MU," Working Paper, U niversity of E xeter.

Wyplosz, C. (2002a) "Fiscal Policy: Rules or Institutions?, Stabiliseringspolitik i valutaunionen. SOU 2002:16 Underlagsrapporter. Stockholm: Fritzes, 291-328.

Wyplosz, C. (2002b) "A Better Way to Balance the Budget," Financial Times, 4 D ecember. 